Gordan Struic**

\title{
PRAVNO UREĐENJE PREDSTAVKI U REPUBLICI HRVATSKOJ - PITANJE KOHERENTNOSTI NORMATIVNOG OKVIRA, POTENCIJALNI PROBLEMI U PRIMJENI I MOGUĆA RJEŠENJA
}

Sažetak: $\quad$ Polazeći od toga da je ustavno pravo na predstavku, kao dio šireg pojma prava peticije, uređeno nizom različitih zakona i drugih propisa u Republici Hrvatskoj, u ovom radu nastoji se odgovoriti na istraživačko pitanje je li važeći normativni okvir uređenja predstavki koherentan. U tom cilju, u radu se pristupa pojmovnom određenju predstavke i izlaže način njezina pravnog uređenja u Republici Hrvatskoj, nakon čega se pobliže razmatraju razlike u važećem normativnom okviru i mogući problemi koji izviru iz postojećeg načina razrade toga ustavnog prava, ali i sugeriraju potencijalna rješenja. Usto, razmatraju se stvarni učinci izloženih propisa na postupanje državnih i drugih tijela po predstavkama, kao i različiti pristupi uređenju predstavki u usporednom pravu. Na toj podlozi, izvodi se zaključak o nekoherentnosti važećega normativnog okvira uređenja predstavki koji izvire iz, prvo, razlika u terminologiji, drugo, nepostojanja ustavne i zakonske definicije predstavke, treće, razlika u rokovima za davanje odgovora na predstavku, četvrto, razlika s obzirom na ovlaštenike prava na predstavku i, peto, razlika u pogledu sankcija za osobe koje onemogućuju ostvarenje toga ustavnog prava.

Ključne riječi: $\quad$ peticija, predstavka, pritužba, prijedlog, Ustav

\section{UVOD}

Iako u predstavničkom sustavu vlasti građani korištenjem svojega biračkog prava izabiru svoje predstavnike, formirajući time posrednika koji postoji između, s jedne strane, birača i, s druge strane, države, odnosno njezinih tijela, u postupnom razvoju ustavne demokracije građanima je omogućeno i neposredno obraćanje državi, odnosno njezinim tijelima, a jedno od

Gordan Struić, mag. iur., univ. spec. pol. Hrvatski sabor, Trg sv. Marka 6, 10000 Zagreb, Republika Hrvatska. Adresa e-pošte: gordan.struic@gmail.com. ORCID: http://orcid.org/0000-0001-6528-4436.

U radu su izneseni osobni stavovi autora. 
prava koja su građanima takvo što trebala omogućiti predstavlja pravo peticije. ${ }^{1}$ Ustavnopravna teorija poznaje distinkciju između peticije u širem i užem smislu. Tako je pod pojmom peticije u širem smislu moguće razumjeti žalbu, predstavku ili pritužbu, koju može podnijeti svatko, neovisno o tome uživa li politička prava - dakle, može je podnijeti i osoba koja nije državljanin odnosne države - dok se pod pojmom peticije u užem smislu podrazumijevaju različiti prijedlozi za rješavanjem pojedinih pitanja iz nadležnosti predstavničkog tijela - koje mogu podnositi isključivo građani s političkim pravima - poput prijedloga, odnosno mišljenja o određenom prijedlogu zakona. ${ }^{2}$ Pravo peticije sadržano je u čl. 46. Ustava Republike Hrvatske $^{3}$ (dalje: Ustav) kojim je određeno da "svatko ima pravo slati predstavke i pritužbe, davati prijedloge državnim i drugim javnim tijelima i dobiti odgovor". Iz toga slijedi da je hrvatski ustavotvorac povezao pravo peticije u širem smislu s pravom peticije u užem smislu, izrijekom predvidjevši i pravo na dobivanje odgovora na peticiju, pa je, zapravo, riječ o "sadržajno najšire oblikovanom pravu peticije", ${ }^{4}$ dok je daljnju razradu tako oblikovanog prava peticije prepustio uređenju zakonom, odnosno drugim propisom.

Polazeći od toga da je ustavno pravo na predstavku, kao dio šireg pojma prava peticije, uređeno nizom različitih zakona i drugih propisa u Republici Hrvatskoj, u ovom radu nastoji se odgovoriti na istraživačko pitanje je li važeći normativni okvir uređenja predstavki koherentan. U tom cilju, nakon prvoga, uvodnog dijela rada, u drugom dijelu pristupa se pojmovnom određenju predstavke, dok se u trećem dijelu izlaže način njezina pravnog uređenja u Republi-

1 Bačić, A., Komentar Ustava Republike Hrvatske, Pravni fakultet Sveučilišta u Splitu, Split, 2002., str. 133. Pravo peticije poznavala je već Magna Charta Libertatum iz 1215., kao jamstvo podanicima da se slobodno, bez straha od odmazde i sankcija, mogu obratiti kralju i od njega zatražiti da bez odgode eliminira povredu nekoga njihova prava (Uzelac, A., Ustavno pravo na žalbu u građanskim stvarima: jamstvo ispravnog pravosuđenja ili relikt prošlosti?, u: A. Uzelac; J. Garašić; A. Maganić (ur.), Djelotvorna pravna zaštita u pravičnom postupku (Liber amicorum Mihajlo Dika), Pravni fakultet Sveučilišta u Zagrebu, Zagreb, 2013., str. 229.). Nakon što je predstavka duže vrijeme služila podaniku kao sredstvo obraćanja višoj vlasti molbom da se akt niže vlasti kojim je nezadovoljan stavi izvan snage ili preinači u njegovu korist, po razvoju građanskih demokracija i jačanju načela zakonitosti dolazi do postupnog preobražaja predstavke u pravo žalbe, ali uz zadržavanje obaju tih instituta - u tom smislu, Ivančević navodi da se u francuskom pravu i danas razlikuje predstavka pod karakterističnim izrazom recours gracieux od hijerarhijske žalbe pod izrazom recours hiérarchique. Vidi: Ivančević, V., Institucije upravnog prava, knj. I., Pravni fakultet u Zagrebu, Zagreb, 1983., str. 170. Pritom, pravo na podnošenje predstavki u suvremenom kontekstu, kao što se ističe u Izvješću o aktivnostima Odbora za predstavke Europskog parlamenta tijekom 2015. od 2. prosinca 2016. (2016/2146(INI)), "mora biti ključan element participativne demokracije u kojoj se na učinkovit način štiti pravo svakog građana na izravnu ulogu u demokratskom životu Unije”.

2 Sruk, J., Ustavno uređenje Socijalističke Federativne Republike Jugoslavije, Informator, Zagreb, 1982., str. 183.; Sokol, S., Valković, Lj., Komentar Ustava Socijalističke Federativne Republike Jugoslavije, CIP, Zagreb, 1990., str. 194. Iako potonjim određenjem pravo peticije u užem smislu nalikuje narodnoj inicijativi - s obzirom na to da građani imaju pravo podnijeti prijedlog (točnije, riječ je o njihovoj inicijativi) predstavničkom tijelu za donošenje određenog zakona, njegove izmjene i/ili dopune - razlika je u tome što se kod narodne inicijative mora provesti cijeli zakonodavni postupak, dok peticiju može odmah odbaciti radno tijelo parlamenta nadležno za postupanje po peticijama, kao i u tome što peticiju u užem smislu može uputiti pojedini državljanin, dok narodnu inicijativu može koristiti "samo određena veća skupina ili postotak birača" (Smerdel, B., Sokol, S., Ustavno pravo, Pravni fakultet Sveučilišta u Zagrebu, Zagreb, 2006., str. 231.).

3 Narodne novine, broj 56/1990, 135/1997, 8/1998, 113/2000, 124/2000, 28/2001, 41/2001, 55/2001, 76/2010, 85/2010, 5/2014 Usto, valjalo bi istaknuti i da je u Povelji Europske unije o temeljnim pravima (Službeni list EU, C 202/02 od 7. lipnja 2016.) predviđeno pravo na podnošenje peticije, i to odredbom čl. 44. prema kojoj "svaki građanin Unije i svaka fizička ili pravna osoba s boravištem ili sjedištem u nekoj državi članici ima pravo na podnošenje peticije Europskom parlamentu”. Nadalje, u čl. 20. st. 2. podst. d) Ugovora o funkcioniranju Europske unije (Službeni list EU, C 202/01 od 7. lipnja 2016.), propisano je pravo građana Europske unije na podnošenje peticije Europskom parlamentu, Europskom ombudsmanu te institucijama i savjetodavnim tijelima Europske unije "na bilo kojem jeziku Ugovorâ te pravo na odgovor na istom jeziku”. Također, prema čl. 227. istog ugovora, svaki građanin Europske unije i svaka fizička ili pravna osoba koja ima boravište ili registrirano sjedište u nekoj od država članica ima pravo, "pojedinačno ili zajedno s drugim građanima ili osobama, podnijeti peticiju Europskom parlamentu u vezi s pitanjem koje ulazi u područje djelovanja Unije te koje neposredno utječe na podnositelja". Sâm postupak po predstavkama uređen je Poslovnikom Europskog parlamenta i Prilogom VI. (XX.) tom Poslovniku (URL=http://www.europarl.europa.eu/sipade/rules/20170116/Rules20170116-HR.epub; pristupljeno 28. veljače 2018.), a nadležni parlamentarni odbor za postupanje po njima je Odbor za predstavke. 
ci Hrvatskoj. Nakon što se u četvrtom dijelu rada razmotre razlike u važećem normativnom okviru i mogući problemi koji izviru iz važećeg načina razrade toga ustavnog prava, u petom dijelu istražuju se stvarni učinci izloženih propisa na postupanje državnih i drugih tijela po predstavkama, dok se u šestom dijelu razmatraju različiti pristupi uređenju predstavki u usporednom pravu. U sedmom, završnom dijelu rada pristupa se zaključnim razmatranjima te se sugeriraju potencijalna rješenja.

\section{POJMOVNO ODREĐENJE PREDSTAVKE}

Na samom početku ovog rada, napose s obzirom na to da niti Ustav niti zakoni u kojima se koristi pojam predstavke ne sadrže njezinu definiciju, valjalo bi utvrditi što se podrazumijeva pod tim pojmom. Prema Hrvatskom jezičnom portalu, predstavka ${ }^{5}$ je svaki pismeni podnesak, odnosno "pismeno obraćanje vlastima ili višim službenim tijelima”. ${ }^{6}$ U nastojanju za pobližim određenjem tog pojma, vrijedi spomenuti definiciju koju daje Krbek, prema kojemu je predstavka neformalni pravni lijek kojim se pokreće određeni “državni organ, da po službenoj dužnosti kao zaštitnik društvenog interesa nešto poduzme (...)”. ${ }^{7}$ Nadalje, predstavka je općenito određena i kao "sredstvo da se iz prikupljenih informacija mogu povući izvjesne konzekvence, da se može utjecati na onu pojavu u upravi o kojoj smo informacije prikupili”. ${ }^{8}$ Od novije literature moglo bi se, primjerice, izdvojiti Opći pravni rječnik kojim je predstavka pobliže određena kao "pritužba, molba ili drugi podnesak kojim se netko obraća tijelima vlasti radi zaštite svojih prava ili pokretanja odgovarajućeg postupka", ${ }^{9}$ što je slično Pravnom leksikonu u kojemu je predstavka definirana kao "podnesak, molba, pritužba i dr. kojim se osoba obraća drž. i drugim tijelima radi pokretanja postupka ili učinkovitijeg ostvarivanja i zaštite svojih prava". ${ }^{10}$ Iako se potonje dvije definicije razlikuju u tome što prvi izvor predstavku supsumira pod pojam podneska, dok drugi izvor u tome ostaje nedorečen izjednačujući je s podneskom, molbom, pritužbom, ali “i dr." (premda ne određuje što bi to "drugo" moglo biti, ako već nije riječ o podnesku), iz obiju tih definicija proizlazi da predstavku može podnijeti svaka osoba, fizička ili

5 Posebno vrijedi istaknuti da se kroz povijest predstavka nazivala i reprezentacijom pa se u pojedinim izvorima iz 19. stoljeća mogu pratiti oba pojma (vidi, primjerice: Šulek, B., Hrvatsko-ugarski ustav ili konstitucija, Brzotis Ant. Jakića, Zagreb, 1861., str. 92.), dok se pojam reprezentacije tek potkraj 19. stoljeća počinje rabiti u značenju političke reprezentacije (vidi pobliže: Ravlić, S., Dileme političkog predstavništva, Politička kultura, Zagreb, 2008., str. 53.). Nadalje, u parlamentarnim poslovnicima od 1875. do danas može se primijetiti još nekoliko pojmova za predstavku koji su se mogli popratiti i u nazivu parlamentarnoga radnog tijela nadležnog za postupanje po predstavkama. Tako, primjerice, Poslovnik Sabora Kraljevinah Hrvatske, Slavonije i Dalmacije od 12. lipnja 1875. (Tiskom Lav. Hartmána i družbe, Zagreb, 1875., str. 16.) u čl. 22. st. 1. t. 9. spominje Odbor za peticije i pritužbe. Sedamdesetak godina poslije, Poslovnik Ustavotvornog sabora Narodne Republike Hrvatske (Narodne novine, broj 143/1946) u čl. 29. st. 1. t. 5. predviđa Odbor za molbe i žalbe, dok je Ustav Narodne Republike Hrvatske (Narodne novine, broj 7/1947) propisao pravo građana na "molbe i peticije organima državne vlasti". Potom je 1958. Poslovnik Sabora Narodne Republike Hrvatske (Narodne novine, broj 57/1958) u čl. 91. t. 4. predvidio radno tijelo nadležno za "predstavke i žalbe" (Odbor za predstavke i žalbe), a 1965. Poslovnik Sabora Socijalističke Republike Hrvatske (Narodne novine, broj 22/1965) u čl. 100. t. 3. radno tijelo za "predstavke i pritužbe" (Komisija za predstavke i pritužbe). Kao što će u radu biti prikazano, neujednačena terminologija nastavljena je i u važećem normativnom okviru uređenja predstavki.

6 Hrvatski jezični portal, URL=http://hjp.znanje.hr. Pristupljeno 28. veljače 2018.

7 Krbek, I., Osnovi upravnog prava FNRJ, Izdavački zavod JAZU, Zagreb, 1950., str. 470.

8 Pusić, E.; Ivanišević, S.; Pavić, Ž.; Ramljak, M., Upravni sistemi, Narodne novine, Zagreb, 1988., str. 165.

9 Vidaković-Mukić, M., Opći pravni rječnik, Narodne novine, Zagreb, 2015., str. 1046. 
pravna, obraćajući se državnim (i drugim) tijelima, radi pokretanja postupka ili (ostvarivanja i) zaštite njezinih prava. Ipak, iz tih definicija nije jasno kada će se neka predstavka moći nazvati, primjerice, molbom ili pritužbom, no može se zauzeti stajalište da bi takav naziv trebao odgovarati njezinu sadržaju, kao i cilju koji se podnošenjem predstavke želi postići. ${ }^{11}$

Pojedini autori, pak, ukazuju na definiciju koja je proizašla iz prakse sâmih državnih tijela u njihovu postupanju po predstavkama. Smolčić, tako, ističe stav Ministarstva unutarnjih poslova Republike Hrvatske (dalje: MUP RH) prema kojemu je predstavka "svaki pisani ili izrečeni podnesak u kojem se na rad ustrojstvenih jedinica MUP-a RH ili na rad i ponašanje njegovih zaposlenika iskazuje nezadovoljstvo ili se iznosi prijedlog da se što učini ili poduzme". ${ }^{12}$ Usto, isti autor ističe kako su se u praksi MUP-a RH pojavile "četiri podvrste predstavki - pritužba, prijava, prigovor i prijedlog"13 pa valja zaključiti da je i u ovom pokušaju određenja predstavke korišten vrlo široki pristup kojim se pod taj pojam nastoji podvesti nekoliko vrsta podnesaka koji se pojavljuju u praksi, ali s time što su te vrste podnesaka ovdje taksativno navedene. Slično tome, na praksu MUP-a RH poziva se i Juras koji, međutim, ukazuje na postojanje razlike između predstavke i pritužbe, pri čemu se najprije referira na definiciju predstavke koju je dao Ured za unutarnju kontrolu MUP-a RH - odredivši je kao "predmet u kojem podnositelj ili skripter općenito iznosi i ukazuje na uočene nepravilnosti ili nezakonitosti u radu i postupanju policijskih djelatnika" ${ }^{14}$ - a, potom, ${ }^{15}$ i na njezinu definiciju iz čl. 2. st. 1. podst. 1. Pravilnika o načinu rada i postupanja po predstavkama i pritužbama, vođenju Evidencije predstavki i pritužbi te o radu Povjerenstva ${ }^{16}$ (dalje: Pravilnik iz 2012.) koji je donio tadašnji ministar unutarnjih poslova. Prema potonjoj odredbi, predstavka je bila određena kao "svaki čitko napisan i potpisan podnesak u kojem podnositelj ukazuje na nezakonitu ili nepravilnu radnju policijskog službenika ili drugog zaposlenika Ministarstva (...), odnosno ustrojstvene jedinice policije ili druge ustrojstvene jedinice Ministarstva, a koja nije u izravnoj vezi s njim i ne odnosi se na njega osobno". Ipak, po stupanju na snagu Pravilnika o načinu rada i postupanja po pritužbama te radu povjerenstava za rad po pritužbama ${ }^{17}$ (dalje: Pravilnik iz 2015.), prestale su važiti sve odredbe Pravilnika iz 2012., pa tako i ona u kojoj je bila sadržana definicija predstavke, dok se u Pravilniku iz 2015. pojam predstavke više ne spominje, već samo pojam pritužbe. ${ }^{18}$

11 U tom smislu, nije naodmet spomenuti i pokušaj da se s obzirom na kriterij sadržaja i namjene svi podnesci razvrstaju u tri skupine, i to prema tome - krajnje pojednostavnjeno rečeno - je li riječ o podnescima kojima se nešto moli ili zahtijeva (molbe) ili kojima se netko protiv nečega žali (žalbe) ili kojima netko ukazuje na nešto (predstavke). Vidi pobliže: Japunčić, J., Kako se sastavljaju molbe, žalbe i predstavke, Birotehnika, Zagreb, 1956., str. 5.

Vidi pobliže: ibid.

Juras, D., Neka pitanja postupka po predstavkama i pritužbama s osvrtom na praksu Ministarstva unutarnjih poslova, Zbornik radova Pravnog fakulteta u Splitu, god. 36, br. 1-2, 1999., str. 330. Pritužba je, pak, određena kao "predmet u kojemu se podnositelj ili skripter konkretno žali i ukazuje na događaj u kojem je izravno oštećen neprofesionalnim, netaktičnim ili nezakonitim postupkom ili propuštanjem postupanja policijskog djelatnika" (ibid.).

15 Juras, D., O predstavkama i pritužbama Ministarstvu unutarnjih poslova Republike Hrvatske, Zbornik radova Pravnog fakulteta u Splitu, god. 50, br. 3, 2013., str. 646.-647.

Narodne novine, broj 58/2012, 43/2013, 33/2015, 78/2015. U tom pravilniku pritužba je, pak, bila definirana kao "svaki čitko napisan i potpisan podnesak u kojem podnositelj ukazuje na nezakonitu ili nepravilnu radnju policijskog službenika ili drugog zaposlenika Ministarstva, odnosno ustrojstvene jedinice policije ili druge ustrojstvene jedinice Ministarstva, prema njemu osobno, uslijed čega on smatra da su povrijeđena neka njegova prava" (čl. 2. st. 1. podst. 1.).

18 Pritom je zanimljiv pristup donositelja da je negativno odredi, propisujući u čl. 2. st. 1.-2. ono što se u smislu tog Pravilnika ne smatra pritužbom - podnesak u kojemu se iznose prethodno razmatrane činjenice koje su ocijenjene u postupku provjere navoda 
Iz dosad izloženog slijedi da i dalje ne postoji jedinstvena i općeprihvaćena pravna definicija predstavke, iako postoji nekoliko pokušaja njezina formuliranja, kako na razini teorije, tako i na razini prakse. Uz to, vrijedi uočiti da je - izuzev primjera u kojima se ukazuje na razliku između predstavke i pritužbe (Juras), odnosno predstavke, molbe i žalbe (Japunčić) - u većini primjera korišten vrlo široki pristup kojim je pojam predstavke korišten kao krovni pojam kojim se nastoji obuhvatiti nekoliko različitih podnesaka, poput molbe, pritužbe, prijave i prigovora, pri čemu se ti podnesci navode taksativno ili egzemplifikativno, no zajedničko im je to da pod pojmom predstavke izrijekom uključuju (i) pritužbe. Premda bi se načelno valjalo prikloniti takvom pristupu širokog određenja predstavke, poput onog iz Općega pravnog rječnika - i to kako bi se pravom iz čl. 46. Ustava obuhvatilo što više podnesaka kojima se njihovi podnositelji mogu obratiti državnim i drugim tijelima, ${ }^{19}$ bez bojazni da bi ih naziv i sadržaj nekog podneska mogao ograničiti u ostvarivanju toga njihovog ustavnog prava (i prava na dobivanje odgovora) - polazeći od jezične interpretacije odredbe čl. 46. Ustava, u kojoj se navode "predstavke i pritužbe", pod pojam predstavke ipak ne bi trebalo podvesti i pritužbu. Stoga, dok bi se na tragu izloženih definicija pod pojmom predstavke mogao općenito odrediti podnesak kojim se svatko može obratiti državnim i drugim tijelima, primjerice, kako bi od tih tijela ishodio pokretanje nekog postupka, ispunjenje neke svoje molbe ili, pak, kako bi im uputio neku svoju primjedbu, komentar ili sugestiju, pod pojmom pritužbe mogao bi se odrediti (samo onaj) podnesak kojim se svatko može obratiti (tj. pritužiti) nadležnom državnom i drugom tijelu, ako smatra da su ugrožena ili povrijeđena neka njegova prava. Polazeći od takvog određenja, valjalo bi se osvrnuti na način pravnog uređenja predstavke u Republici Hrvatskoj.

\section{NORMATIVNI OKVIR}

Ustavno pravo na predstavku regulirano je nizom zakona i drugih propisa. Primjerice, $\mathrm{u}$ čl. 26. Zakona o lokalnoj i područnoj (regionalnoj) samoupravi ${ }^{20}$ određeno je da su tijela jedinica lokalne i područne (regionalne) samouprave obvezna "omogućiti građanima i pravnim osobama podnošenje predstavki i pritužbi na svoj rad kao i na rad njihovih upravnih tijela te na nepravilan odnos zaposlenih u tim tijelima kad im se obraćaju radi ostvarivanja svojih prava i interesa ili izvršavanja svojih građanskih dužnosti” (st. 1.). U tom cilju, navedena tijela moraju na vidljivom mjestu u službenim prostorijama osigurati potrebna sredstva kako bi se predstavke i pritužbe mogle podnositi (npr. knjigu za pritužbe), ali i omogućiti da se one mogu usmeno izjavljivati (st. 3.). U slučaju podnošenja predstavke ili pritužbe, čelnici navedenih tijela obvezni su na njih dati odgovor, i to u roku od 30 dana od dana njihova podnošenja (st. 2.). Ako bi čelnici navedenih tijela zloupotrijebili svoj položaj ili ovlast kako bi spriječili drugoga u korištenju njegova prava na podnošenje predstavke ili pritužbe - što je prema ne-

pritužbe istog podnositelja te podnesci koji se tiču radnji u postupku ostvarivanja prava za čije rješavanje je nadležan MUP RH, i to: zahtjevi, žalbe, prigovori i drugi podnesci u upravnom ili prekršajnom postupku.

19 Usp. Smolčić, P., Predstavke na rad zaposlenika i ustrojstvenih jedinica MUP-a RH, Policija i sigurnost, god. 16, br. 3-4, 2007., str. 204.-205.

20 Narodne novine, broj 33/2001, 60/2001, 129/2005, 109/2007, 36/2009, 125/2008, 36/2009, 150/2011, 144/2012, 19/2013, $137 / 2015,123 / 2017$. 
kadašnjem čl. 112. Kaznenog zakona ${ }^{21}$ iz 1997. izrijekom bilo ${ }^{22}$ propisano kao kazneno djelo povrede prava na podnošenje pravnih lijekova i predstavki - na temelju čl. 13. st. 2. t. 3. važećeg Zakona o lokalnim izborima, ${ }^{23}$ koji se i dalje poziva na čl. 112. Kaznenog zakona iz 1997., birači i političke stranke ne bi mogli za člana predstavničkog tijela jedinice, općinskog načelnika, gradonačelnika, župana i njihova zamjenika kandidirati onoga koji je za to kazneno djelo pravomoćnom sudskom odlukom osuđen (uključujući i uvjetnu osudu) na kaznu zatvora u trajanju od najmanje šest mjeseci. ${ }^{24}$ Usto, kako je previđeno Zakonom o službenicima i namještenicima u lokalnoj i područnoj (regionalnoj) samoupravi, ${ }^{25}$ ako bi službenici onemogućili građane i pravne osobe u ostvarenju njihova prava na podnošenje predstavke (ili zahtjeva, žalbi, prigovora i drugih zakonskih prava), počinili bi tešku povredu službene dužnosti (čl. 46. st. 1. t. 10.). Međutim, nijedan od istaknutih zakona ne definira što se pod pojmovima predstavke i pritužbe podrazumijeva.

Zakon o državnim službenicima ${ }^{26}$ sadrži jednu odredbu koja se tiče prava na predstavku, predviđajući u čl. 14. da državni službenik ima pravo dati "prijedloge u vezi s ostvarivanjem prava iz državne službe, uputiti predstavku i pritužbu te dobiti na njih odgovor”, pri čemu nije određen rok za postupanje po predstavci i pritužbi odnosno za odgovor podnositelju, niti je određeno što se pod pojmovima predstavke i pritužbe podrazumijeva. Nadalje, pravo na predstavku i pritužbu predviđa, ali ih pobliže ne određuje, i Zakon o državnom odvjetništvu, ${ }^{27}$ kojim je izrijekom određeno pravo svakog da ministarstvu nadležnom za poslove pravosuđa ili nadležnom državnom odvjetniku podnese pisanu ili usmenu predstavku i pritužbu na rad dotičnog (ili nižega) državnog odvjetništva, kao i pravo da na njih dobije odgovor u roku od 30 dana od dana njihova zaprimanja u nadležnom državnom odvjetništvu (čl. 5.). Usto, državno odvjetništvo može od građana tražiti obavijesti glede njihovih “prijava, podnesaka, pritužbi i predstavki” (čl. 50. st. 2.). Iako pojmove predstavke i pritužbe koristi (ali ne i definira) i Zakon o sudovima, ${ }^{28}$ to je učinjeno nedosljedno. Naime, za razliku od čl. 36. st. 3. podst. 4., u kojemu je propisano da tajnik suda po ovlaštenju predsjednika suda, među ostalim, odgovara na predstavke i pritužbe stranaka koje su podnesene na rad suda, u čl. 4. st. 3. određeno je samo pravo na predstavku na rad suda ili suca koju, u pisanom ili usmenom obliku svatko može podnijeti predsjedniku suda ${ }^{29}$ (i dobiti odgovor), ako smatra da je došlo do odugovlačenja postupka u

21 Narodne novine, broj 110/1997, 27/1998, 50/2000, 129/2000, 84/2005, 51/2001, 111/2003, 190/2003, 105/2004, 71/2006, 110/2007, 152/2008, 57/2011, 77/2011, 125/2011, 143/2012. Čl. 112. tadašnjega Kaznenog zakona glasio je: "Službena ili odgovorna osoba koja zlouporabom svojega položaja ili ovlasti spriječi drugoga da se koristi svojim pravom podnošenja žalbe, prigovora, molbe, predstavke ili pritužbe, kaznit će se novčanom kaznom ili kaznom zatvora do jedne godine."

Važeći Kazneni zakon (Narodne novine, broj 125/2011, 144/2012, 56/2015, 61/2015, 101/2017) više ne predviđa kazneno djelo povrede prava na podnošenje pravnih lijekova i predstavki.

23 Narodne novine, broj 144/2012, 121/2016.

24 Uz to, valjalo bi naglasiti i kako je zakonodavac u istoj odredbi propisao da se mora raditi o onim djelima koja su "počinjena s namjerom i radi pribavljanja imovinske koristi ili kakve druge koristi sebi ili drugoj osobi” (vidi čl. 13. st. 2. t. 3. Zakona o lokalnim izborima).

25 Narodne novine, broj 86/2008, 61/2011, 4/2018.

26 Narodne novine, broj 92/2005, 140/2005, 142/2006, 77/2007, 107/2007, 27/2008, 34/2011, 49/2011, 150/2011, 34/2012, 38/2013, 37/2013, 1/2015, 138/2015, 61/2017.

27 Narodne novine, broj 76/2009, 153/2009, 116/2010, 145/2010, 57/2011, 130/2011, 72/2013, 148/2013, 33/2015, 82/2015

28 Narodne novine, broj 28/2013, 33/2015, 82/2015, 82/2016

29 O spomenutoj temi vidi pobliže i: Rajko, A., Predstavke (požurnice) upućene predsjednicima sudova, 2016. URL=http://www.iusinfo. com.hr/DailyContent/Topical.aspx?id=28440 (pristupljeno 28. veljače 2018.) i Juras, D., Predstavke i pritužbe na rad i ponašanje državnih službenika, državnih odvjetnika i sudaca, Hrvatska pravna revija, god. 8, br. 12, 2008., str. 11.-18. 
kojemu je stranka ili u njemu ima pravni interes, odnosno da se sudac ili drugi zaposlenik pri službenim odnosima sa strankom nedolično ili neprimjereno ponašao, suprotno etičkom kodeksu. U tom slučaju predsjednik suda ima obvezu odgovoriti na predstavku najkasnije u roku od 30 dana od dana njezina zaprimanja. Uz to, i u čl. 29. st. 1. t. 9. spominju se samo predstavke, u odredbi prema kojoj poslovi sudske uprave obuhvaćaju, među ostalim, i poslove "u svezi s predstavkama stranaka na rad suda".

U Zakonu o referendumu i drugim oblicima osobnog sudjelovanja u obavljanju državne vlasti i lokalne i područne (regionalne) samouprave ${ }^{30}$ (dalje: Zakon o referendumu) nije predviđeno pravo na pritužbu, već pravo na predstavku koja je u čl. 2. st. 2., uz državni, lokalni i savjetodavni referendum te mjesne zborove građana, tek općenito određena kao oblik neposrednog odlučivanja i izjašnjavanja birača u obavljanju državne vlasti te lokalne i područne (regionalne) samouprave, dok je njezino pobliže određenje i u ovom zakonu izostalo. Prema čl. 63., građani mogu podnijeti predstavke tijelima državne vlasti i tijelima jedinica lokalne i područne (regionalne) samouprave, ali - za razliku od ostalih zakona koji propisuju da "svatko" ima pravo na predstavku, što je izraz koji je korišten i u čl. 46. Ustava - Zakon o referendumu propisuje da predstavke mogu podnijeti samo građani s biračkim pravom (čl. 65. st. 1.), tj. hrvatski državljani s navršenih 18 godina (čl. 45. st. 1. Ustava). Usto, prema Zakonu o referendumu, građani moraju potpisati predstavku i na njoj navesti svoje ime i prezime te osobni identifikacijski broj (čl. 63. st. 2.). Rok za odgovor tijela državne vlasti i tijela jedinice lokalne i područne (regionalne) samouprave nije preciziran, već ta tijela moraju odgovoriti podnositelju u "primjerenom roku" (čl. 64.). S obzirom na to da je u čl. 65. st. 2. Zakona o referendumu propisano da predstavke "ne obvezuju tijelo kojem se podnose", valjalo bi spomenuti kako je u Odluci Ustavnog suda Republike Hrvatske broj U-III-234/1998 od 28. travnja 1999., ${ }^{31}$ istaknuto da tijelo sudbene vlasti svojom presudom ne bi moglo "obvezati državno ili drugo javno tijelo, pa ni osobu kojoj je predstavka upućena da na predstavku odgovori”. Međutim, imajući u vidu da svatko ima pravo dobiti odgovor na predstavku na temelju čl. 46. Ustava, nedobivanje odgovora na podnesenu predstavku dovelo bi do povrede njegova ustavnog prava iz čl. 46. Ustava.

Nadalje, ustavno pravo na predstavku regulirano je i u Poslovniku Hrvatskoga sabora, ${ }^{32} \mathrm{u}$ čijem je čl. 44. st. 6. propisano da radna tijela Hrvatskoga sabora mogu "raspraviti o predstavkama i prijedlozima” podnesenima Hrvatskom saboru, ali bez njihove definicije. Ujedno, isti stavak određuje i daljnju proceduru, propisujući da će predstavku ili prijedlog ${ }^{33}$ građana za donošenje zakona ili drugih akata upućenu Hrvatskom saboru predsjednik Hrvatskoga sabora proslijediti predsjedniku matičnoga radnog tijela ${ }^{34}$ koji mora obavijestiti podnositelja o rezultatu ("ishodu") njegove predstavke ili prijedloga najkasnije u roku od tri mjeseca. Usto, Poslovnik Hrvatskoga sabora predviđa radno tijelo u čiji djelokrug ulazi razmatranje predstavki, pritužbe i prijedloga upućenih Hrvatskom saboru i ukazivanje na povrede zakona i prava građana u postupcima pred

30 Narodne novine, broj 33/1996, 92/2001, 44/2006, 58/2006, 69/2007, 38/2009, 100/2016, 73/2017.

31 Narodne novine, broj 46/1999.

32 Narodne novine, broj 81/2013, 113/2016, 69/2017. Pritom, valja spomenuti da je Ustavni sud Republike Hrvatske (dalje: Ustavni sud) u Odluci broj U-II-1744/2001 od 11. veljače 2004. (Narodne novine, broj 21/2004) utvrdio kako Poslovnik Hrvatskoga sabora, s obzirom na njegov "Ustavom propisani način donošenja i predmet uređenja, ima pravnu snagu zakona".

33 Iako pritužbe nisu spomenute u istoj odredbi, vrijedi ih uočiti u nizu drugih odredbi koje se navode u nastavku ovog rada, poput čl. 79. st. 3., čl. 95. st. 1. podst. 6., čl. 107. i čl. 164. st. 2. Poslovnika Hrvatskoga sabora.

34 Na temelju čl. 3. st. 1. podst. 4. Poslovnika Hrvatskoga sabora, matično radno tijelo je "svako radno tijelo Sabora koje prati, raspravlja i zauzima stajališta o pitanjima o određenoj temi iz svog djelokruga". 
tijelima državne uprave i pravnim osobama s javnim ovlastima. Riječ je o Odboru za predstavke i pritužbe ${ }^{35}$ (čl. 107.) u čiji djelokrug ulazi i ukazivanje na povrede zakona i ostale štetne pojave sa širim značenjem i predlaganje mjera radi njihova otklanjanja, ispitivanje osnovanosti predstavki, pritužbe i prijedloga te ukazivanje na potrebu poduzimanja mjera, o čemu mora izvijestiti podnositelja, ali i podnošenje godišnjeg izvješća Hrvatskom saboru o svom radu. S Odborom za predstavke i pritužbe, sukladno čl. 79. st. 3., surađuje saborski Odbor za ljudska prava i prava nacionalnih manjina ${ }^{36}$ koji može razmatrati sva pitanja za koja ocijeni da su bitna za zaštitu ljudskih ili etničkih prava, a posebno valja uočiti i mogućnost donošenja akta (preporuke) od strane Hrvatskoga sabora radi ukazivanja na određene predstavke i pritužbe o nepravilnostima u radu pravnih osoba s javnim ovlastima, uz prijedlog njihova rješenja (čl. 164. st. 2.).

S druge strane, Etički kodeks državnih službenika ${ }^{37}$ (dalje: Etički kodeks) ne predviđa pravo na predstavku već samo pravo na pritužbu, i to bez određivanja što se pod tim pojmom podrazumijeva, s time da čelnik državnog tijela mora odgovoriti podnositelju pritužbe u roku od 60 dana od dana zaprimanja pritužbe te ga izvijestiti o radnjama koje su poduzete (čl. 22. st. 1.). Zanimljivo je da ni Zakon o pučkom pravobranitelju ${ }^{38}$ ne određuje pravo na predstavku, već pravo na pritužbu (bez njezine definicije), svakome tko smatra da su nezakonitim ili nepravilnim radom tijela ugrožena ili povrijeđena ustavna ili zakonska prava i slobode, radi pokretanja postupka. (čl. 20. st. 1.), s time da pučki pravobranitelj mora izvijestiti podnositelja "u što kraćem roku” o razlozima "zbog kojih neće postupati po pritužbi” (čl. 22. st. 4.). Sličan pristup zakonodavca vidljiv je i u Zakonu o policiji ${ }^{39}$ koji također ne predviđa pravo na predstavku, nego pravo na pritužbu (i u ovom zakonu bez njezine definicije) koju može podnijeti svaka fizička ili pravna osoba koja "smatra da su njoj ili drugoj osobi djelovanjem ili propuštanjem djelovanja policijskog službenika, u primjeni policijskih ovlasti, povrijeđena prava ili slobode” (čl. 5. st. 1.), s time da je podnositelja potrebno obavijestiti o utvrđenom činjeničnom stanju i poduzetim mjerama, u roku od 30 dana od dana primitka pritužbe (čl. 5.a st. 2.). Nadalje, ni Zakon o sustavu državne uprave ${ }^{40}$ ne spominje pojam predstavke, već prigovora i pritužbe, propisujući u čl. 84. st. 1. obvezu svih tijela državne uprave da građanima i pravnim osobama omoguće podnošenje prigovora i pritužbi na rad tijela državne uprave te na "nepravilan odnos državnih službenika kad im se obraćaju radi ostvarivanja svojih prava i interesa ili izvršavanja svojih građanskih dužnosti”. U tom cilju, navedena tijela moraju na vidljivom mjestu osigurati potrebna tehnička i druga sredstva za podnošenje prigovora i pritužbi, kao i mogućnost usmenog podnošenja prigovora odnosno pritužbe, a čelnik tog tijela na čiji se rad prigovara, odnosno pritužuje, mora na njih odgovoriti u roku od 30 dana od dana njihova podnošenja (st. 2.-4.). Usto, isti zakon propisuje i obvezu predstojnika ureda državne uprave u jedinicama područne (regionalne) samouprave da o podnesenim prigovorima, odnosno pritužbama, zna-

35 Prema čl. 108. Poslovnika Hrvatskoga sabora, Odbor za predstavke i pritužbe ima predsjednika, potpredsjednika i jedanaest članova iz reda zastupnika u Hrvatskom saboru, dok se članovi iz reda javnih, znanstvenih i stručnih djelatnika u to radno tijelo ne imenuju.

36 Međutim, ako je riječ o pritužbama kojima se "ukazuje na štetne radnje glede devastacije okoliša", za postupanje po njima i ispitivanje njihove utemeljenosti, sukladno izričitoj odredbi čl. 95. st. 1. podst. 6. Poslovnika Hrvatskoga sabora, bit će nadležan isključivo Odbor za zaštitu okoliša i prirode.

37 Narodne novine, broj 40/2011, 13/2012. Navedeni kodeks sadrži odredbe o načinu podnošenja pritužbe (čl. 18.) i ispitivanju njezine osnovanosti (čl. 19.-24.).

38 Narodne novine, broj 76/2012.

39 Narodne novine, broj 34/2011, 130/2012, 89/2014, 151/2014, 33/2015, 121/2016. 
čajnijim primjedbama i prijedlozima te o poduzetim mjerama izvijeste nadležno ministarstvo, središnji državni ured, odnosno državnu upravnu organizaciju (čl. 85.).

Iako bi se moglo izdvojiti još sličnih zakonskih, ${ }^{41}$ ali i podzakonskih ${ }^{42}$ primjera uređenja prava na predstavku, valjalo bi sažeti i jasno istaknuti razlike u izloženom normativnom okviru te skrenuti pozornost na probleme koji izviru iz važećeg načina razrade toga ustavnog prava.

\section{NEKOHERENTNOST I POTENCIJALNI PROBLEMI}

Iz dosad izloženog slijedi zamjetna nekoherentnost važećega normativnog okvira uređenja predstavki koja je vidljiva već iz prvog pogleda na pojmove koji se u tom okviru koriste, kao

41 Vidi npr. čl. 28. Zakona o inspekcijama u gospodarstvu (Narodne novine, broj 14/2014, 56/2016) kojim je propisano da će inspektor pri ocjeni postoje li razlozi za pokretanje postupka ex officio uzeti u obzir "predstavke koje upućuju na potrebu zaštite javnog interesa", ali bez definicije predstavke i preciziranja roka za obavještavanje podnositelja o utvrđenom stanju i poduzetim mjerama (slično je propisano i kod poduzimanja izvanrednog nadzora na temelju čl. 46. st. 3.-4.); čl. 42. st. 2.-3. Zakona o općem upravnom postupku (Narodne novine, broj 47/2009) kojim je određeno da javnopravno tijelo pri ocjeni postoje li razlozi za pokretanje postupka po službenoj dužnosti uzima u obzir "predstavke, odnosno druge obavijesti koje upućuju na potrebu zaštite javnoga interesa" (bez definicije predstavke, ali uz pojašnjenje u čl. 71. st. 1. da se predstavke smatraju "podnescima u postupku"), s time da službena osoba mora obavijestiti podnositelja "što je prije moguće, a najkasnije u roku od 30 dana od dana podnošenja predstavke, odnosno obavijesti” o tome da nema uvjeta za pokretanje postupka po službenoj dužnosti; čl. 378. st. 3.-4. Zakona o osiguranju (Narodne novine, broj 30/2015) koji predviđa pravo na predstavku "zainteresirane osobe" iz čl. 375. t. 1.-2. Hrvatskoj agenciji za nadzor financijskih usluga (ali bez definicije predstavke), i određuje obvezu obavještavanja podnositelja predstavke "što je prije moguće, a najkasnije u roku od 30 dana od završene provjere navoda iz predstavke"; čl. 43. Zakona o pravu na pristup informacijama (Narodne novine, broj 25/2013, 85/2015) kojim je propisano da se inspekcijski nadzor obavlja "povodom zaprimljenih predstavki korisnika prava na pristup informacijama i ponovnu uporabu informacija, na prijedlog treće strane ili po službenoj dužnosti” te čl. 59. st. 1. i 5. koji uređuju postupanje inspektora po predstavkama na rad tijela javne vlasti u vezi primjene tog zakona, ali bez definicije predstavke i preciziranja roka u kojemu inspektor mora pisanim putem izvijestiti podnositelja u pogledu utvrđenih činjenica i poduzetih mjera; čl. 116. st. 1. Zakona o proračunu (Narodne novine, broj 87/2008, 109/2007, 136/2012, 15/2015) prema kojemu se proračunski nadzor obavlja, uz ostalo, i po predstavkama građana, bez definiranja predstavke i preciziranja roka za obavještavanje podnositelja.

42 Vidi npr. Pravilnik o postupku s predstavkama i pritužbama (Narodne novine, broj 142/1999) Upravnog vijeća Hrvatskog zavoda za mirovinsko osiguranje, kojim je uređen postupak po predstavkama, pritužbama i prijedlozima osiguranika, korisnika prava iz mirovinskog osiguranja i drugih fizičkih i pravnih osoba u vezi s provedbom mirovinskog osiguranja, pri čemu se pod predstavkom, pritužbom i prijedlogom podrazumijevaju "molbe, pritužbe, drugi podnesci te evidentirane usmene izjave, upućene radi ostvarivanja i zaštite prava te pravnih interesa iz mirovinskog osiguranja, odnosno radi pokretanja inicijativa šireg značenja i interesa u sklopu provedbe mirovinskog osiguranja i drugih prava koja se ostvaruju u Zavodu" (čl. 2. st. 1.); Pravilnik o nadzoru nad provedbom Zakona o javnoj nabavi (Narodne novine, broj 65/2017) koji je donijelo Ministarstvo gospodarstva, poduzetništva i obrta radi određivanja sadržaja i oblika predstavke kojom se traži provedba upravnog nadzora, sadržaja zapisnika o provedenom nadzoru i druga pitanja o provedbi nadzora; čl. 14. st. 7. Pravilnika o načinima, postupcima i elementima vrednovanja učenika u osnovnoj i srednjoj školi (Narodne novine, broj 112/2010) koji je donijelo tadašnje Ministarstvo znanosti, obrazovanja i športa (današnje Ministarstvo znanosti i obrazovanja), prema kojemu "roditelj/i ima pravo na pisane i usmene predstavke (primjedbe, komentare i sugestije) o vrednovanju učenika koje podnose ravnatelju i/ili vijeću roditelja”, a ravnatelj na nju mora "pisano odgovoriti najkasnije u roku od 15 dana od dana zaprimanja predstavke" (čl. 16. st. 3.); Pravilnika o provođenju unutarnjeg nadzora i unutarnje kontrole u Carinskoj upravi (Narodne novine, broj 153/2013) Ministarstva financija prema čijem su čl. 27. st. 2. t. 1. predstavke oblik "saznanja od fizičkih i pravnih osoba", a kao primjeri tih saznanja navode se "pritužbe, prijave, prigovori, prijedlozi i slično". Uz navedene pravilnike, valjalo bi izdvojiti i Protokol o postupanju po predstavkama $i$ pritužbama, kojim se uređuje postupanje po predstavkama i pritužbama građana, korisnika prava i usluga iz socijalne skrbi i drugih fizičkih i pravnih osoba u pogledu provedbe propisa iz djelokruga (nekadašnjeg) Ministarstva socijalne politike i mladih (današnjeg Ministarstva za demografiju, obitelj, mlade i socijalnu politiku). Naime, navedenim protokolom - koji nije objavljen u Narodnim novinama već na internetskoj stranici: URL=http://www.mspm.hr/istaknute-teme/nadzor-i-predstavke/protokolo-postupanju-po-predstavkama-i-prituzbama/880 (pristupljeno 28. veljače 2018.) - predstavka i pritužba predstavljaju "svaki čitko pisani podnesak te evidentirana usmena izjava upućena radi ostvarivanja prava i usluga iz djelokruga rada Ministarstva” (čl. II. st. 1.), s time da je pobliže određeno da se pod predstavkom razumijevaju "upit, zamolba i prijedlog vezan uz ostvarivanje pojedinog prava iz djelokruga rada Ministarstva” (čl. II. st. 3.). Iako je i takvo određenje predstavke prilično šturo, s obzirom na to da je riječ o taksativnom (a ne egzemplifikativnom) navođenju - tek triju - spomenutih podnesaka, riječ je o jednom od rijetkih primjera određivanja predstavke na podzakonskoj razini u cilju razrade ustavnog prava na predstavku. 
i nepostojanja ustavne i zakonske definicije pojma predstavke. Naime, u dosadašnjem dijelu rada utvrđeno je da se u normativnom okviru koriste različiti izrazi. Neki propisi uz pojam predstavke vežu pojam pritužbe, koristeći izraz "predstavka i pritužba" (npr. Zakon o lokalnoj i područnoj (regionalnoj) samoupravi, Zakon o državnim službenicima, Zakon o državnom odvjetništvu, Zakon o sudovima i Poslovnik Hrvatskoga sabora), neki koriste isključivo pojam predstavke (npr. Zakon o referendumu) ili, pak, samo pojam pritužbe (npr. Zakon o pučkom pravobranitelju, Zakon o policiji i Etički kodeks), ili uopće ne spominju predstavku, već koriste izraz "prigovor i pritužba" (npr. Zakon o sustavu državne uprave), dok se u nekim propisima istodobno koriste dva izraza (npr. "predstavka i pritužba” i "predstavka” u Zakonu o sudovima).

Uz navedene razlike u terminologiji i nepostojanje ustavne i zakonske definicije, u dosadašnjem dijelu rada utvrđene su i razlike u rokovima u kojima državna i druga tijela moraju odgovoriti na podnesenu predstavku. Naime, u nekim propisima navedeni rok nije preciziran (npr. u Zakonu o državnim službenicima i Zakonu o referendumu, s time da je u potonjem zakonu određen kao "primjereni rok"), dok je u nekim propisima preciziran, ali uz daljnje razlike pa tako u nekim propisima rok traje tri mjeseca, i to bez određivanja trenutka od kojega rok počinje teći (u Poslovniku Hrvatskoga sabora), dok u nekim propisima taj rok traje 30 dana, ali se razlikuje s obzirom na to počinje li rok teći od dana podnošenja (npr. u Zakonu o lokalnoj i područnoj (regionalnoj) samoupravi) ili, pak, od dana zaprimanja (npr. u Zakonu o državnom odvjetništvu i Zakonu o sudovima). Uz to, među propisima koji umjesto pojma predstavke koriste pojam pritužbe moguće je razlikovati one kod kojih rok za odgovor traje 60 dana i računa se od dana njezina zaprimanja (npr. u Etičkom kodeksu), propise kod kojih rok za odgovor nije preciziran (npr. u Zakonu o pučkom pravobranitelju), kao i propise kod kojih taj rok traje 30 dana i počinje teći od dana primitka pritužbe (npr. u Zakonu o policiji), odnosno od dana podnošenja prigovora i pritužbe (npr. u Zakonu o sustavu države uprave).

Nadalje, valjalo bi ukazati na određene razlike među izloženim propisima s obzirom na to tko je ovlašten podnijeti predstavku, kao i s obzirom na sankcije za osobe koje su onemogućile ovlaštenike u ostvarenju njihova prava na podnošenje predstavke. Naime, za razliku od većine zakonskih rješenja, koja svakome daju pravo na predstavku, u Zakonu o referendumu propisano je da predstavke mogu podnijeti samo građani s biračkim pravom, tj. ne pravne, već samo fizičke osobe, i to (samo) one koje su hrvatski državljani s navršenih 18 godina. Ujedno, za razliku od većine propisa koji ne predviđaju sankcije za onemogućavanje ovlaštenika prava na podnošenje predstavke, prema Zakonu o službenicima i namještenicima u lokalnoj i područnoj (regionalnoj) samoupravi takvo onemogućavanje od strane službenika predstavljalo bi tešku povredu njegove službene dužnosti. Također, valja istaknuti da je u važećem Zakonu o lokalnim izborima sadržana zabrana kandidiranja osoba koje su pravomoćnom sudskom odlukom osuđene na kaznu zatvora u trajanju od najmanje šest mjeseci zbog povrede prava na podnošenje pravnih lijekova i predstavki, ali pritom treba primijetiti da je povreda spomenutog prava izrijekom bila propisana u Kaznenom zakonu iz 1997., dok važećim Kaznenim zakonom iz 2011. navedena povreda, na koju se poziva važeći Zakon o lokalnim izborima, više nije predviđena kao kazneno djelo.

Slijedom svega navedenog, nameće se zaključak o nekoherentnosti važećega normativnog okvira uređenja predstavki čije je oživotvorenje povezano s potencijalnim problemima koji izviru iz razlika u terminologiji, nepostojanja ustavne i zakonske definicije, razlika u rokovima 
u kojima državna i druga tijela moraju odgovoriti na podnesenu predstavku, kao i u ovlašteniku prava na podnošenje predstavke te sankcijama za osobe koje su onemogućile ovlaštenike u ostvarenju toga njihova ustavnog prava. Primjerice, ako neki zakon predviđa isključivo pravo na pritužbu, bez navođenja pojma predstavke ili njezina sadržajnog podvođenja pod pojam pritužbe, znači li to da se njime implicite onemogućuje pravo na predstavku unatoč izričitoj odredbi čl. 46. Ustava? Uz to, podnese li građanin predstavku tijelu jedinice lokalne i područne (regionalne) samouprave i, primjerice, ne navede zakonski već ustavni temelj za njezino podnošenje, može li očekivati da će odgovor dobiti u "primjerenom roku", na temelju čl. 64 . Zakona o referendumu, ili, pak, u roku od 30 dana od dana podnošenja predstavke, na temelju čl. 26. st. 2. Zakona o lokalnoj i područnoj (regionalnoj) samoupravi? Štoviše, podnese li predstavku istom tijelu neka udruga, hoće li to tijelo morati postupati po predstavci na temelju potonjeg zakona ili će se pozvati na čl. 65. st. 1. Zakona o referendumu, na temelju kojeg podnositelji ne mogu biti pravne osobe, nego "građani koji imaju biračko pravo"?

Polazeći od imperativa koji pred zakone nameće vladavina prava, koja predstavlja jednu od najviših vrednota ustavnog poretka iz čl. 3. Ustava i čini temelj za tumačenje Ustava, a napose od načela pravne sigurnosti, izvjesnosti i dosljednosti, ${ }^{43}$ normativni okvir prava na predstavku ne bi trebao ostavljati mjesta prethodno spomenutim (i sličnim) pitanjima. Naime, jedna od temeljnih postavki svakoga pravnog poretka koji počiva na vladavini prava jest, kako to ističe Ustavni sud, ${ }^{44}$ da "zakoni moraju biti opći i jednaki za sve, a zakonske posljedice trebaju biti izvjesne za one na koje će se zakon primijeniti”, kao i "primjerene legitimnim očekivanjima stranaka u svakom konkretnom slučaju u kojem se zakon na njih neposredno primjenjuje”. Iz toga slijedi da zakonska odredba mora biti posve jasno i precizno formulirana kako bi se spriječila (ili barem na najmanju moguću mjeru svela) mogućnost njezine različite interpretacije te osigurala izvjesnost zakonskih posljedica za one na koje se ta odredba ima primijeniti.

Imajući to u vidu, valjalo bi razmotriti i stvarne učinke izloženih propisa na postupanje državnih i drugih tijela po podnesenim predstavkama.

\section{STVARNI UČINCI PROPISA}

U nastojanju za istraživanjem stvarnih učinaka izloženih propisa na postupanje tijela po podnesenim predstavkama, ključni problem s podacima koji se na njih odnose proizlazi upravo iz nekoherentnosti važećega normativnog okvira uređenja predstavki. Naime, polazeći od prethodno spomenutih razlika među propisima u terminologiji, definiciji, ovlasti za podnošenje, rokovima za odgovor i sankcijama, najprije vrijedi istaknuti da postupanje po predstavka-

43 U tom smislu, vidi npr. Rješenje Ustavnog suda Republike Hrvatske broj: U-I-3101/2014 i dr. od 12. siječnja 2015. (Narodne novine, broj 5/2015). Usto, Europski sud za ljudska prava u presudi Beian protiv Rumunjske, od 6. prosinca 2007., zahtjev br. 30658/05 (URL= http://www.legal-tools.org/doc/a40617/pdf/; pristupljeno 28. veljače 2018.), u $\$ 39$ naglašava kako je načelo pravne sigurnosti (principle of legal certainty) jedno od temeljnih elemenata vladavine prava, a navedena presuda često se citira i u hrvatskoj ustavnosudskoj praksi. Vidi npr. Odluku i Rješenje Ustavnog suda Republike Hrvatske broj: U-I-3843/2007 od 6. travnja 2011. (Narodne novine, broj 48/2011), Odluku i Rješenje Ustavnog suda Republike Hrvatske broj: U-I-722/2009 od 6. travnja 2011. (Narodne novine, broj 44/2011) te Odluku i Rješenje Ustavnog suda Republike Hrvatske broj: U-I-4039/2009, U-I25427/2009 i U-I-195/2010 od 18. srpnja 2014. (Narodne novine, broj 100/2014) itd. 
ma za sva državna i druga tijela nije uređeno na jedinstven način, ne postoji samo jedno tijelo koje bi bilo ovlašteno zaprimati predstavke i postupati po njima, baš kao što ne postoji niti središnji registar predstavki, niti sustav koji bi omogućio praćenje njihova statusa od strane podnositelja ili državnih i drugih tijela. Stoga, istražujući postupanje pojedinih tijela po predstavkama koje su im podnesene, do određenih podataka - poput onih o nepostupanju po određenoj predstavci, odnosno o proteku roka za odgovor, ispravnom klasificiranju zaprimljenog podneska kao predstavke ili ishodu u slučaju nezadovoljstva podnositelja odgovorom - moglo bi se doći izravno tek po uvidu u pojedini spis predmeta ili, pak, neizravno, preko godišnjih izvješća pojedinih tijela, ali u potonjem slučaju bez dubljeg uvida kojim bi se omogućila sustavna analiza dostupnih podataka. Time bi se istraživanje moglo znatnije oduljiti, naročito ako se njime obuhvaća duže razdoblje, ali i usložniti, posebice u slučaju usporedne analize podataka različitih tijela. Štoviše, s obzirom na razliku u terminologiji, kod upućivanja podneska identičnog sadržaja na adrese, primjerice, dvaju tijela, posve je moguće da se zaprimljeni podnesak identičnog sadržaja u jednom tijelu klasificira kao predstavka, a u drugom kao pritužba, zbog primjene zakona koji izrijekom predviđa isključivo podnošenje predstavke (poput Zakona o referendumu) i zakona koji dopušta podnošenje pritužbe i predstavke (poput Zakona o lokalnoj i područnoj (regionalnoj) samoupravi) te da se provedu dva postupka po, suštinski, istoj stvari.

Uz to, premda se do određenih podataka o postupanju pojedinih državnih tijela po podnesenim predstavkama može doći i preko njihovih godišnjih izvješća, metodologija njihove izrade nije jedinstvena. Naime, u nekim izvješćima ističu se podaci o broju zaprimljenih ${ }^{45}$ ili broju zaprimljenih i riješenih predstavki uz prikaz njihove strukture/sadržaja, ${ }^{46}$ odnosno uz kratak opis najčešćih razloga podnošenja i podnositelja, ${ }^{47}$ dok neka izvješća sadrže i podatak o zaprimljenim podnescima koji se tiču nezadovoljstva dugotrajnošću i ishodima postupaka ispitivanja predstavki koji se vode pred drugim tijelima. ${ }^{48}$ Iako bi se među izvješćima tijela posebno moglo izdvojiti ono koje obuhvaća sve prethodno spomenute podatke - riječ je o godišnjem izvješću koje sukladno čl. 107. st. 1. podst. 4. Poslovnika Hrvatskoga sabora o svojem radu podnosi Odbor za predstavke i pritužbe - kod njega se također mogu primijetiti izvjesna ograničenja u potencijalnom istraživanju ove materije, primjerice, zbog neredovitosti tog izvješća u parlamentarnoj praksi, ${ }^{49}$ ali i zbog toga što je riječ o izvješću koje izrađuje tek jedno radno tijelo Hrvatskoga sabora, dok matična radna tijela nisu detaljnije obuhvaćena spomenutim izvješćem (niti bi, prema važećem poslovničkom rješenju, morala biti) niti su ga sâma obvezna izraditi.

S druge strane, unatoč navedenim ograničenjima u istraživanju stvarnih učinaka izloženih propisa, iz podataka u godišnjim izvješćima pojedinih tijela mogu se uočiti neki od problema

45 Vidi npr. Izvješće o radu Hrvatske energetske regulatorne agencije za 2016. godinu. Riječ je o izvješću koje je Hrvatski sabor prihvatio 6. listopada 2017. URL=http://www.sabor.hr/fgs.axd?id=49766. Pristupljeno 28. veljače 2018.

46 Vidi npr. Izvješće o radu Agencije za zaštitu osobnih podataka za 2016. godinu. Riječ je o izvješću koje je Hrvatski sabor prihvatio 13. listopada 2017. URL=http://www.sabor.hr/fgs.axd?id=49669. Pristupljeno 28. veljače 2018.

47 Vidi npr. Izvješće o radu Državnog odvjetništva Republike Hrvatske za 2016. godinu. Riječ je o izvješću koje se nalazi na dnevnom redu 7. sjednice Hrvatskoga sabora. URL=http://www.sabor.hr/fgs.axd?id=48956. Pristupljeno 28. veljače 2018.

48 Vidi npr. Izvješće pučke pravobraniteljice za 2016. godinu. Riječ je o izvješću koje je Hrvatski sabor prihvatio 27. listopada 2017. URL=http://www.sabor.hr/fgs.axd?id=48673. Pristupljeno 28. veljače 2018.

49 Uvidom u e-Doc bazu podataka Hrvatskoga sabora (URL=http://edoc.sabor.hr; pristupljeno 28. veljače 2018.) može se primijetiti da nedostaju izvješća o radu Odbora za predstavke i pritužbe za 2006., 2007., 2010. i 2011. godinu. 
koje je moguće pripisati nekoherentnosti važećega normativnog okvira uređenja predstavki na koje je ukazano u prethodnom poglavlju, poput nejasnog ishoda podnesaka po kojima tijela postupaju na temelju različitih propisa, znatnih razlika u praksi pridržavanja rokova za odgovor podnositelju itd.

Primjerice, u Izvješću o radu Odbora za predstavke i pritužbe za 2016. godinu ${ }^{50}$ navodi se da je taj Odbor zaprimao pritužbe vezane uz statusna prava građana i "pojedinačnu predstavku u kojoj podnositelj upozorava na potrebu uspostave civilnog nadzora nad radom policije”, pri čemu je "takve predstavke Odbor (...) nakon razmatranja dostavljao na mjerodavno postupanje Ministarstvu unutarnjih poslova...”. Međutim, uvidom u Izvješće ministra unutarnjih poslova o obavljanju policijskih poslova u 2016. godini ${ }^{51}$ može se primijetiti podatak da je na razini cijelog MUP-a RH zaprimljeno 2311 pritužbi i anonimnih podnesaka, dok se ni u jednom dijelu potonjeg izvješća ne spominju predstavke, ${ }^{52}$ kao ni Odbor za predstavke i pritužbe, pa iz tog izvješća ostaje nejasan njihov ishod, tj. jesu li odbačene, (pre)klasificirane u pritužbe itd.

Nadalje, iako je Zakonom o državnom odvjetništvu predviđeno pravo podnositelja predstavke i pritužbe na odgovor $\mathrm{u}$ jasno određenom roku, u trajanju od 30 dana od dana njihova zaprimanja u nadležnom državnom odvjetništvu, u Izvješću pučke pravobraniteljice za 2016. godinu navodi se da je u toj godini pučka pravobraniteljica zaprimila ukupno 320 pritužbi, pri čemu iz pojedinih pritužbi proizlazi da "državno odvjetništvo i dalje ne komunicira s građanima na zadovoljavajući način, ne odgovara na njihove predstavke i ne daje informacije o stanju predmeta", i da "niti ove godine DORH (...) nije dostavio podatke o broju zaprimljenih pritužbi”. Istodobno, u Izvješću o radu Državnog odvjetništva Republike Hrvatske za 2016. godinu nije naveden podatak o tome je li podnositeljima u propisanom roku bilo odgovoreno na predstavke. Za razliku od takve prakse postupanja, u Izvješću o radu Odbora za predstavke i pritužbe za 2016. godinu izrijekom je navedeno da su sve pisane predstavke i pritužbe (ukupno 317 predmeta) u roku od 30 dana obrađene i upućene nadležnim tijelima na postupanje, o čemu su podnositelji obaviješteni, odnosno da je u roku od 30 dana izravno odgovoreno podnositeljima predstavki, premda je Poslovnikom Hrvatskoga sabora predviđen rok od tri mjeseca. Stoga, uz vrlo različito određene rokove za odgovor podnositeljima na predstavke, i uz nepostojanje zakonskih sankcija u slučaju njihova nepridržavanja, mogu se uočiti posve različite prakse tijela u pridržavanju rokova.

Na tom tragu, valjalo bi spomenuti da je u Izvješću o radu Odbora za predstavke i pritužbe za 2016. godinu sadržan podatak o uspješnosti rješavanja zaprimljenih predstavki i pritužbi u korist građana, i to u iznosu od $17,98 \%$, iz čega slijedi da se građanima pomoglo u ostvarivanju njihovih prava i interesa u 57 od 317 predmeta, ali pritom nisu navedeni kriteriji na temelju kojih se pojedini predmet može smatrati uspješno riješenim i koliko je od tog broja bilo predstavki, a koliko pritužbi te jesu li tim brojem bili obuhvaćeni i ostali podnesci, poput mišljenja, komentara i osvrta građana, koji prema tom izvješću ulaze u ukupni broj predmeta u 2016. Usto, podatak o broju riješenih predmeta, ali bez navođenja postotka uspješnosti njihova rješavanja

50 Navedeno izvješće prihvaćeno je 6. listopada 2017., a dostupno je na URL=http://www.sabor.hr/fgs.axd?id= 48551. Pristupljeno 28. veljače 2018.

51 Navedeno izvješće nalazi se na dnevnom redu 7. sjednice Hrvatskoga sabora, a dostupno je na URL=http://www.sabor.hr/fgs. axd?id=49056. Pristupljeno 28. veljače 2018.

52 Takav pristup zacijelo se može opravdati terminologijom korištenom u Zakonu o policiji koji ne predviđa pravo na predstavku, već pravo na pritužbu. 
u korist građana, nalazi se, primjerice, i u Izvješću o radu Agencije za zaštitu osobnih podataka za 2016. godinu (od 417 predstavki u 2016. godini i 110 predstavki prenesenih iz ranijeg razdoblja riješeno ih je 428, tj. 81,21\%) i Izvješću o provedbi Zakona o pravu na pristup informacijama za 2016. godinu ${ }^{53}$ (od 326 predstavki u 2016. godini i 103 predstavke prenesene iz ranijeg razdoblja riješeno je 237 predstavki, tj. 55,50\%), dok iz Izvješća o radu Državnog odvjetništva Republike Hrvatske za 2016. godinu nije razvidno koliko je od ukupno 106 zaprimljenih predstavki i pritužbi riješeno i s kojim ishodom. Iako bi se iz navedenih podataka mogao steći dojam da je pojedino tijelo više ili manje uspješno u odnosu na drugo u rješavanju zaprimljenih predstavki, vrijedi napomenuti da bi se prije izvođenja ikakvog zaključka koji bi išao u tom smjeru najprije moralo poći od identičnih i posve jasnih kriterija na temelju kojih se pojedini predmet uopće smatra "riješenim" za određeno tijelo (primjerice, hoće li biti dostatno da je podnositelju upućena obavijest o prosljeđivanju predstavke nadležnom tijelu ili da je tom tijelu nadležno tijelo poslalo svoj odgovor na znanje ili će, pak, biti dovoljan protek nekog vremena tijekom kojeg podnositelj nije uputio nikakav podnesak u povodu odgovora, odnosno očitovanja tijela), ali i pritom uzeti u obzir postojanje nemalih razlika u ukupnom broju predstavki zaprimljenih u jednom izvještajnom razdoblju i broju predstavki koje su prenesene iz prethodnog razdoblja.

Imajući u vidu navedena ograničenja, ali i podatke iz godišnjih izvješća pojedinih tijela u kojima se mogu zapaziti neki od problema koje je moguće pripisati nekoherentnosti važećega normativnog okvira uređenja predstavki na koje je bilo ukazano u dosadašnjem dijelu rada, prije nego što se pristupi zaključnim razmatranjima valjalo bi se još osvrnuti i na pojedina rješenja ove materije iz usporednog prava.

\section{PRISTUPI UREĐENJU PREDSTAVKI U USPOREDNOM PRAVU}

Razmatrajući način uređenja prava na predstavku, kao dijela šireg pojma prava peticije, u usporednom pravu mogu se uočiti različiti pristupi. Na ustavnoj razini, ono je propisano u nizu država - primjerice, ustavom Bugarske ${ }^{54}$ (čl. 45.), Cipra $^{55}$ (čl. 29. st. 1.), Estonije ${ }^{56}$ (čl. 46.), Grčke $^{57}$ (čl. 10. st. 1.), Mađarske ${ }^{58}$ (čl. XXV.), Makedonije ${ }^{59}$ (čl. 24.), Njemačke ${ }^{60}$ (čl. 17.), Polj-

53 Navedeno izvješće prihvatio je Hrvatski sabor 14. srpnja 2017. URL=http://www.sabor.hr/fgs.axd?id=48819. Pristupljeno 28. veljače 2018.

54 Ustav Republike Bugarske (Конституция на Република България), URL=http://www.parliament.bg/bg/const. Pristupljeno 28 veljače 2018.

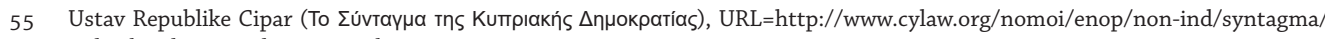
index.html. Pristupljeno 28. veljače 2018.

56 Ustav Republike Estonije (Eesti Vabariigi põhiseadus), URL=https://www.riigiteataja.ee/akt/633949. Pristupljeno 28. veljače 2018.

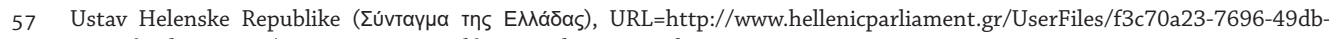
9148-f24dce6a27c8/SYNTAGMA1_1.pdf. Pristupljeno 28. veljače 2018.

58 Mađarski Temeljni zakon (Magyarország Alaptörvénye), URL=www.parlament.hu/irom39/02627/02627.pdf. Pristupljeno 28. veljače 2018.

59 Ustav Republike Makedonije (Устав на Република Македонија), URL=https://www.sobranie.mk/WBStorage/Files/UstavnaRmizmeni. pdf. Pristupljeno 28. veljače 2018.

60 Temeljni zakon Savezne Republike Njemačke (Grundgesetz für die Bundesrepublik Deutschland), URL=http://www.gesetze-iminternet.de/gg/index.html. Pristupljeno 28. veljače 2018. 
ske $^{61}$ (čl. 63.), Portugala ${ }^{62}$ (čl. 52. st. 1.), Ruske Federacije $e^{63}$ (čl. 33.), Slovačke ${ }^{64}$ (čl. 27. st. 1.), Slovenije ${ }^{65}$ (čl. 45.) i Srbije ${ }^{66}$ (čl. 56.). U pravilu, riječ je o ustavnim odredbama tek načelnoga karaktera, dok je daljnja razrada tog prava prepuštena uređenju zakonom, odnosno drugim propisom. Međutim, postoje i ustavi koji uz propisivanje prava na predstavku ${ }^{67}$ sadrže i odredbe o njezinu obliku (npr. ciparski, grčki, mađarski i njemački ustav zahtijevaju isključivo pisani oblik obraćanja državnim i drugim tijelima); pravu podnositelja na odgovor (npr. ciparski, makedonski, portugalski, srbijanski ustav), odnosno obvezi tijela da mu odgovori (npr. grčki ustav); roku za odgovor (npr. portugalski ustav spominje "razumni rok", ciparski ustav rok koji "nije dulji od trideset dana”, a grčki ustav zahtijeva "brzo djelovanje javne vlasti”), dok se u nekim ustavima mogu pronaći i odredbe o nadležnom parlamentarnom tijelu za postupanje po predstavkama (npr. njemački ustav u čl. 45c sadrži odredbu o imenovanju odbora nadležnog za peticije u Bundestagu).

Na potonjem tragu, valjalo bi primijetiti da pojedine države parlamentarnim poslovnikom propisuju nadležnost posebnoga radnog tijela. Primjerice, u Poslovniku njemačkog Bundestaga $^{68}$ razrađene su odredbe čl. 17. i čl. 45.c njemačkog ustava, i to propisivanjem nadležnosti Odbora za peticije (čl. 108.) koje mu uputi predsjednik Bundestaga (čl. 109.), kao i propisivanjem ovlasti tog Odbora za donošenje načela postupanja po podnescima (čl. 110.), odnosno prijenosa ovlasti Odbora na njegove pojedine članove (čl. 111.), izvješća tog Odbora (s preporukom) o peticijama koje mora uputiti Bundestagu jedanput na mjesec te godišnjeg izvješća Bundestagu o svom radu (čl. 112.). Ujedno, ovlasti tog Odbora uređuje i Zakon o ovlastima Odbora za peticije njemačkog Bundestaga ${ }^{69}$ kojim je, inter alia, propisano da su, u cilju pripreme odluka Odbora za peticije, savezna vlada i druga tijela savezne vlasti dužni dostaviti dokumentaciju tom Odboru, ustupiti mu podatke i omogućiti pristup njihovim prostorijama (čl. 1.), s time da je Odbor za peticije ovlašten i saslušati podnositelja prijave, svjedoke i stručnjake (čl. 4.). Uz to, na temelju čl. 110. Poslovnika njemačkog Bundestaga Odbor za peticije donio je Načela o

61 Ustav Republike Poljske (Konstytucja Rzeczypospolitej Polskiej), URL=http://www.sejm.gov.pl/prawo/konst/polski/kon1.htm. Pristupljeno 28. veljače 2018.

62 Ustav Portugalske Republike (Constituição da República Portuguesa), URL=http://www.parlamento.pt/Legislacao/Documents/ constpt2005.pdf. Pristupljeno 28. veljače 2018.

63 Ustav Ruske Federacije (Конституция Российской Федерации), URL=http://www.ksrf.ru/ru/Info/LegalBases/ConstitutionRF/ Pages/default.aspx. Pristupljeno 28. veljače 2018.

64 UstavSlovačkeRepublike(ÚstavaSlovenskejrepubliky),URL=http://www.nrsr.sk/web/Static/sk-SK/NRSR/Doc/zd-ustava_20170907. pdf. Pristupljeno 28. veljače 2018.

65 Ustav Republike Slovenije (Ustava Republike Slovenije), URL=http://www.pisrs.si/Pis.web/pregledPredpisa?id=USTA1. Pristupljeno 28. veljače 2018.

66 Ustav Republike Srbije (Устав Републике Србије), URL=http://www.parlament.gov.rs/upload/documents/Ustav-Srbije-pdf.pdf. Pristupljeno 28. veljače 2018.

67 Iako pojedini ustavi izrijekom spominju pravo na peticiju, interpretacijom relevantnih ustavnih odredbi i uvidom u podatke iz parlamentarne prakse (vidi npr. informacije na internetskoj stranici Narodne skupštine Republike Srbije: URL=http:// www.parlament.gov.rs/gradjani/pitajte/inicijative,-peticije,-predstavke-i-predlozi.1098.html; pristupljeno 28. veljače 2018.), utvrđeno je da je riječ o pojmu peticije u širem smislu pod koji valja podvesti i predstavku, kao što je pojašnjeno u uvodnom dijelu ovog rada.

68 Poslovnik njemačkog Bundestaga (Geschäftsordnung des Deutschen Bundestages), URL=http://www. bundestag. de/parlament/ aufgaben/rechtsgrundlagen/go-btg/go-btg/197104. Pristupljeno 28. veljače 2018.

69 Zakon o ovlastima Odbora za peticije njemačkog Bundestaga (Gesetz über die Befugnisse des Petitionsausschusses des Deutschen Bundestages), URL=https://www.gesetze-im-internet.de/ggart45cg/GGArt45cG. pdf. Pristupljeno 28. veljače 2018. 
postupanju sa zamolbama i pritužbama ${ }^{70}$ koja dalje razrađuju navedene propise, primjerice, $u$ pogledu oblika podnesaka koji se upućuju tom Odboru (zahtijeva se pisani oblik), razlikovanja peticija (zamolbi, pritužbi, višestrukih, kolektivnih i masovnih peticija te drugih podnesaka) i prosljeđivanja peticija nadležnom tijelu na postupanje (npr. Europskom parlamentu za pitanja iz njegova djelokruga).

Također, posebno parlamentarno radno tijelo za postupanje po predstavkama propisano je i bugarskim Pravilnikom o ustrojstvu i radu Narodne skupštine. ${ }^{71}$ Njime je utvrđena nadležnost Odbora za odnos s nevladinim organizacijama i pritužbe građana (čl. 39.-41.), dok je pobliže uređenje postupanja po podnescima prepušteno Internim pravilima o radu ${ }^{72}$ tog Odbora kojima je u većem dijelu uređena organizacija njegova rada i mogućnost osnivanja savjetodavnog tijela Odbora, a tek u manjem dijelu sâmi podnesci (npr. njihov obvezni sadržaj, pisani oblik i podredna primjena zakona kojim se uređuje upravni postupak na rok za odgovor podnositelju). Istodobno, za razliku od rješenja njemačkog i bugarskoga parlamentarnog poslovnika, postoje primjeri država koje svojim parlamentarnim poslovnikom ne propisuju nadležnost nekoga posebnog radnog tijela. Primjerice, prema Poslovniku Narodne skupštine ${ }^{73}$ Republike Srbije svaki odbor ${ }^{74}$ nadležan je za razmatranje inicijativa, peticija, predstavki i prijedloga iz svog djelokruga (čl. 44. st. 1. podst. 8.), što je u skladu s čl. 15. st. 4. t. 1. Zakona o Narodnoj skupštini ${ }^{75}$ prema kojemu u ostvarivanju predstavničke funkcije Narodna skupština, odnosno narodni poslanici razmatraju predstavke i prijedloge građana. Štoviše, u estonskom Zakonu o internim i postupovnim pravilima Riigikogua ${ }^{76}$ nisu uočene odredbe o nadležnom parlamentarnom radnom tijelu za postupanje po predstavkama, kao ni druge odredbe koje bi uređivale tu materiju, nego je razrada toga ustavnog prava prepuštena zakonodavcu kroz odredbe nekoliko različitih zakona, poput Zakona o kancelaru pravde ${ }^{77}$ (u čl. 23.-25.), Zakona o zaštiti potrošača ${ }^{78}$ (u čl. 46.-47.), Zakona o državnim tajnama i klasificiranim podacima o stranim državama ${ }^{79}$ (u čl. 24. st. 2.) itd.

70 Načela Odbora za peticije o postupanju sa zamolbama i pritužbama (Grundsätze des Petitionsausschusses über die Behandlung von Bitten und Beschwerden), URL=https://www.bundestag.de/ausschuesse/ausschuesse18/a02-18/grundsaetze/ verfahrensgrundsaetze/260564. Pristupljeno 28. veljače 2018.

71 Pravilnik o ustrojstvu i radu Narodne skupštine (Правилник за организацията и дейността на Народното Събрание), URL=http:// www.parliament.bg/bg/rulesoftheorganisations. Pristupljeno 28. veljače 2018.

72 Interna pravila o radu Odbora (Вътрешни правила за работата на Комисията), URL=http://www.parliament.bg/bg/ parliamentarycommittees/members/2592/info. Pristupljeno 28. veljače 2018.

73 Poslovnik Narodne skupštine (Пословник Народне скупштине), URL=http://www.parlament.gov.rs/upload/ documents/ Poslovnik\%20Narodne\%20skupstine\%20-\%20precisceni\%20tekst\%20Sluzbeni\%20g.pdf. Pristupljeno 28. veljače 2018.

74 Ipak, vrijedi napomenuti da je prema čl. 66. st. 1. podst. 9. Poslovnika Narodne skupštine razmatranje prijedloga, peticija i predstavki građana upućenih Narodnoj skupštini u pogledu rada sigurnosnih službi, predlaganje mjera za njihovo rješavanje $i$ informiranje podnositelja o tome izrijekom navedeno u okviru djelokruga Odbora za kontrolu službi bezbednosti.

75 Zakon o Narodnoj skupštini (Закон о Народној скупштини), URL=http://www.parlament.gov.rs/upload/docum ents/412-10.pdf. Pristupljeno 28. veljače 2018.

76 Zakon o internim i postupovnim pravilima Riigikogua (Riigikogu kodu - ja töökorra seadus), URL=https://www.riigiteataja.ee/ akt/128062016022. Pristupljeno 28. veljače 2018.

77 Zakon o kancelaru pravde (Õiguskantsleri seadus), URL=https://www.riigiteataja.ee/akt/128122017020. Pristupljeno 28. veljače 2018.

78 Zakon o zaštiti potrošača (Tarbijakaitseseadus), URL=https://www.riigiteataja.ee/akt/128122017033. Pristupljeno 28. veljače 2018.

79 Zakon o državnim tajnama i klasificiranim informacijama o stranim državama (Riigisaladuse ja salastatud välisteabe seadus), URL=https://www.riigiteataja.ee/akt/105052017005. Pristupljeno 28. veljače 2018. 
S druge strane, zanimljiv pristup uređenju predstavki u usporednom pravu može se uočiti kod država koje posebnim zakonom uređuju postupanje po predstavkama podnesenim državnim i drugim tijelima. Tako su, primjerice, u Poslovniku Sejma Republike Poljske ${ }^{80}$ sa- $^{-}$ držane odredbe o posebnom parlamentarnom radnom tijelu, Odboru za peticije (čl. 18. st. 1. t. 1.a) i tek nekoliko načelnih odredbi o načinu postupanja po podnescima u parlamentu (čl. 126.b-126.g), dok je detaljnije uređenje povjereno posebnom zakonu - Zakonu od 11. srpnja 2014. o peticijama. ${ }^{81}$ Tim zakonom, od svega 17 članaka, određena su pravila za podnošenje i razmatranje peticija ${ }^{82}$ i način na koji tijela vlasti po njima postupaju, a posebice pravila koja se odnose na podnositelja, pisani oblik podnesaka i njihov obvezni sadržaj, vremenski rok za razmatranje podneska (prema čl. 10. st. 1. treba ga razmotriti "bez odgode, a najkasnije 3 mjeseca od dana podnošenja"), dok se na ostala pitanja koja nisu uređena tim zakonom na odgovarajući način primjenjuju odredbe Zakona o upravnom postupku od 14. lipnja $1960 .{ }^{83}$ Sličan pristup uređenju predstavki može se uočiti i u Portugalu. Naime, iako je Poslovnikom Skupštine Republike ${ }^{84}$ određeno da predsjednik Skupštine zaprima i prosljeđuje predstavke nadležnim parlamentarnim radnim tijelima (čl. 16. st. 1. t. i.), u čl. 232. st. 1. izrijekom je navedeno da se ustavno pravo na peticiju ostvaruje sukladno zakonu, a zakon kojemu je povjereno ostvarivanje tog prava donesen je 1990. pod nazivom Lei n. ${ }^{\circ} 43 / 90$, de 10 de agosto. ${ }^{85}$ Riječ je o zakonu koji u 28 članaka uređuje i jamči ostvarivanje ustavnog prava na peticiju (u širem smislu) podnošenjem peticija (u užem smislu), predstavki, prigovora i pritužbi svim tijelima javne vlasti izuzev sudovima (čl. 1. st. 1.). Njime je, poput poljskog Zakona od 11. srpnja 2014. o peticijama, određen niz pravila koja se, među ostalim, pobliže odnose na oblik podnesaka i njihov obvezni sadržaj, ovlast njihova podnošenja i rok za postupanje po podnesku te se njime propisuje, primjerice, da će tijelo javne vlasti odlučiti o sadržaju podneska "što je prije moguće, sukladno složenosti materije” (čl. 13. st. 1.), dok će nadležno radno tijelo parlamenta odlučiti o podnesku u roku od 60 dana od dana njegova zaprimanja (čl. 17. st. 9.). Međutim, za razliku od navedenoga poljskog zakona, portugalski zakon sadrži i definiciju predstavke i drugih podnesaka koji se mogu uputiti tijelima vlasti ${ }^{86}$ (čl. 2.). Vrlo sličan pristup može se primijetiti i u

80 Poslovnik Sejma Republike Poljske (Regulamin Sejmu Rzeczypospolitej Polskiej), URL=http://www.sejm.gov.pl/prawo/ regulamin/kon7.htm. Pristupljeno 28. veljače 2018. Također, i poljski Senat ima posebno radno tijelo koje je nadležno za postupanje po predstavkama. Poslovnik Senata Republike Poljske od 23. studenoga 1990. (Uchwała Senatu Rzeczypospolitej Polskiej z dnia 23. listopada 1990.; URL=https://www.senat. gov.pl/download/gfx/senat/pl/defaultopisy/86/1/1/regulamin-z12-lutego-2018.pdf. Pristupljeno 28. veljače 2018.) u čl. 15. st. 1. t. 6. predviđa nadležnost Odbora za ljudska prava, vladavinu zakona i peticije, a postupanje tog Odbora po podnescima u Senatu uređen je u čl. 90.a-90.g istog Poslovnika.

81 Zakon od 11. srpnja 2014. o peticijama (Ustawa z dnia 11 lipca 2014 r. o petycjach), URL=http://prawo.sejm.gov.pl/isap.nsf/ download.xsp/WDU20140001195/T/D20141195L.pdf. Pristupljeno 28. veljače 2018.

82 Iako je zakonodavac upotrijebio pojam peticije, u poljskoj pravnoj literaturi postoje shvaćanja da je trebalo jasnije odrediti što se sve pod tim pojmom obuhvaća. U tom smislu, vidi npr. Ożóg, M., Uregulowanie instytucji petycji w ustawie z dnia 11 lipca 2014 r. o petycjach, Przegląd Sejmowy, god. 23, br. 5, 2015., str. 117.-142.

83 Zakon o upravnom postupku od 14. lipnja 1960. (Ustawa z dnia 14 czerwca $1960 \mathrm{r}$. Kodeks postępowania administracyjnego), URL=http://prawo.sejm.gov.pl/isap.nsf/download.xsp/WDU19600300168/O/D19600168.pdf. Pristupljeno 28. veljače 2018.

84 Poslovnik Skupštine Republike (Regimento da Assembleia da República), URL=http://www.parlamento.pt/Legislacao/ Documents/Legislacao-Anotada/RegimentoAR-Simples.pdf. Pristupljeno 28. veljače 2018.

85 Zakon broj 43/90, od 10. kolovoza (Lei n. ${ }^{\circ} 43 / 90$, de 10 de agosto), URL=http://www.parlamento.pt/legislacao/documents/ legislacao-anotada/exerciciodireitopeticao-anotado.pdf. Pristupljeno 28. veljače 2018.

86 Sukladno čl. 2. tog zakona, peticijom se upućuje zahtjev ili prijedlog tijelu vlasti radi poduzimanja, usvajanja ili predlaganja određenih mjera; prigovorom se osporavaju određene radnje pred tijelom, dužnosnikom ili službenikom koji ju je poduzeo ili u njoj sudjelovao ili pred njegovim nadređenim; pritužbom se pritužuje na neku neustavnost ili nezakonitost ili nepravilnost rada nekog odjela ili službe u cilju poduzimanja mjera protiv odgovornih; predstavkom se izražava mišljenje suprotno onome koje zauzima neko tijelo javne vlasti ili mu se skreće pozornost na određeni slučaj ili akt u cilju njegove revizije ili razmatranja njegovih 
Rusiji, gdje također postoji poseban zakon kojim se uređuje postupanje po podnescima - riječ je o Saveznom zakonu o postupku razmatranja obraćanja građana Ruske Federacije ${ }^{87}$ koji pod pojmom "obraćanja građana" obuhvaća molbu, pritužbu i prijedlog nekom državnom tijelu, tijelu lokalne samouprave ili službenoj osobi u pisanom obliku ili obliku elektroničkog dokumenta, ali i svako "usmeno obraćanje građana nekom državnom tijelu ili tijelu lokalne samouprave" 88 (čl. 4. st. 1. t. 1.). Navedeni zakon sastoji se od 18 članaka kojima je, među ostalim, određen oblik i obvezni sadržaj "obraćanja građana", rok za njihovo razmatranje (koji prema čl. 12. st. 1. traje, u pravilu, 30 dana od dana njihova zaprimanja), a specifičnost tog zakona u odnosu na prethodno spomenuta zakonska rješenja iz usporednog prava sadržana je u njegovu čl. 16. koji predviđa pravo građana na naknadu materijalne i nematerijalne štete, na temelju sudske odluke, kada je šteta pričinjena nezakonitim postupanjem (ili propuštanjem postupanja) državnih tijela, tijela lokalne samouprave ili službenih osoba pri razmatranju "obraćanja građana". Istodobno, ako bi građanin u svojemu "obraćanju” iznio neistinite podatke, državna tijela, tijela lokalne samouprave ili službene osobe kojima bi pri razmatranju tog "obraćanja" nastala šteta, imali bi pravo od njega sudskim putem tražiti naknadu štete.

Iz dosad izloženog slijedi vrlo različit pristup uređenju predstavki u usporednom pravu. Kao što je prikazano, na ustavnoj razini pravo na predstavku propisano je u nizu država, a daljnja razrada toga ustavnog prava može biti izvršena parlamentarnim poslovnikom - koji, nadalje, može propisati nadležnost posebnoga radnog tijela ili svakoga radnog tijela za razmatranje podnesaka iz svog djelokruga - i/ili jednim posebnim ili više različitih zakona i podzakonskih propisa. Kada se samo jednim, posebnim zakonom uređuje postupanje po predstavkama i drugim podnescima, to je moguće učiniti zakonskim rješenjem koje ne zahtijeva podrednu primjenu drugih zakona, ili, pak, takvim zakonskim rješenjem koje predviđa da će se na pojedina pitanja koja nisu uređena tim zakonom na odgovarajući način primijeniti odredbe jednog ili više drugih zakona. Imajući u vidu spomenute pristupe uređenju predstavki, valjalo bi prijeći na zaključna razmatranja.

\section{ZAKLJUČNA RAZMATRANJA}

Nastojeći pobliže istražiti pravno uređenje ustavnog prava na predstavku, kao dijela šireg pojma prava peticije, koje je u Republici Hrvatskoj uređeno cijelim nizom različitih zakona i drugih propisa, ovim radom nastojalo se odgovoriti na istraživačko pitanje je li važeći normativni okvir uređenja predstavki koherentan. U tom cilju, najprije se pristupilo pojmovnom određenju predstavke i izložilo način njezina pravnog uređenja u Republici Hrvatskoj, nakon čega su bile razmotrene razlike u važećem normativnom okviru, kao i mogući problemi koji

učinaka. Usporedi li se potonja definicija predstavke s onom koja je predložena na početku ovog rada, može se primijetiti da je predložena definicija nešto šira u odnosu na definiciju iz portugalskog zakona, budući da se njome ukazuje na više ciljeva koji se podnošenjem predstavke mogu postići.

87 Savezni zakon o postupku razmatranja obraćanja građana Ruske Federacije (Федеральный закон о порядке рассмотрения обращений граждан Российской Федерации), URL=http://pravo.gov.ru/proxy/ips/?docbody=\&nd=102106413. Pristupljeno 28. veljače 2018 .

88 Imajući u vidu da "obraćanje građana", među ostalim, obuhvaća molbu, može se primijetiti da je suštinski riječ o predstavci, napose s obzirom na definiciju predstavke predložene na početku ovog rada kao podneska kojim se svatko može obratiti državnim i drugim tijelima, primjerice, kako bi od tih tijela ishodio, među ostalim, ispunjenje neke svoje molbe. 
izviru iz važećeg načina razrade toga ustavnog prava. Dodatno, pristupilo se istraživanju stvarnih učinaka izloženih propisa na postupanje državnih i drugih tijela po predstavkama te različitim pristupima uređenju predstavki u usporednom pravu.

U radu je izveden zaključak o nekoherentnosti važećega normativnog okvira uređenja predstavki koji izvire iz, prvo, razlika u terminologiji, drugo, nepostojanja ustavne i zakonske definicije predstavke, treće, razlika u rokovima za davanje odgovora na predstavku, četvrto, razlika s obzirom na ovlaštenike prava na predstavku i, peto, razlika u pogledu sankcija za osobe koje onemogućuju ostvarenje toga ustavnog prava. Na toj podlozi ukazano je na važnost načela pravne sigurnosti, izvjesnosti i dosljednosti pri formuliranju zakonskih odredbi kako bi bile jasne i precizne, sprječavajući, odnosno umanjujući mogućnost njihovih različitih interpretacija i jamčeći time izvjesnost zakonskih posljedica za sve one na koje se ta odredba ima primijeniti.

U nastojanju za istraživanjem stvarnih učinaka propisa spomenutih u ovom radu istaknuta je potreba da se povede računa o trima ograničenjima pri analizi podataka koja se tiču postupanja tijela po podnesenim predstavkama. Prvo, s obzirom na razlike među propisima u terminologiji, definiciji, ovlasti za podnošenje, rokovima za odgovor i sankcijama, potrebno je uzeti u obzir da postupanje državnih i drugih tijela po predstavkama nije uređeno na jedinstven način, ne postoji središnje tijelo nadležno za njihovo zaprimanje, rješavanje i vođenje registra predstavki, kao što ne postoji ni središnji registar predstavki, odnosno sustav koji bi omogućio praćenje njihova statusa. Drugo, do određenih podataka koji bi dali stvarni prikaz postupanja tijela moguće je izravno doći tek po uvidu u pojedini spis predmeta ili, pak, neizravno, preko godišnjih izvješća pojedinih tijela, ali u potonjem slučaju bez dubljeg uvida kojim bi se omogućila sustavna analiza dostupnih podataka; sve to moglo bi znatnije oduljiti i usložniti njihovo istraživanje, naročito u slučaju provođenja usporedne analize podataka različitih tijela. Treće, premda se do određenih podataka o postupanju pojedinih državnih tijela po predstavkama može doći i preko njihovih (godišnjih) izvješća, metodologija njihove izrade nije jedinstvena, a dodatno ograničenje može predstavljati njihova neredovitost i specifičnosti tijela koje ga izrađuje. S druge strane, unatoč spomenutim ograničenjima, iz podataka u godišnjim izvješćima pojedinih tijela uočeni su neki od problema koje je moguće pripisati nekoherentnosti važećega normativnog okvira uređenja predstavki te je ukazano na različitu praksu pojedinih tijela u postupanju po predstavkama na primjeru njihovih godišnjih izvješća koja podnose Hrvatskom saboru, ali i na različitu metodologiju njihove izrade.

Važeći normativni okvir prava na predstavku trebalo bi urediti tako da se otklone utvrđeni nedostaci - prema tome, uskladiti terminologiju u zakonima i drugim propisima, uz nastojanje za definiranjem pojma predstavke i njegovim razlikovanjem od pritužbe (i prijedloga), sukladno čl. 46. Ustava. U tom cilju, imajući u vidu prethodno izložene napomene o pojmovnom određenju predstavke, načelno bi se valjalo prikloniti pristupu njezina širokog određenja - kao podneska kojim se svatko može obratiti državnim i drugim tijelima kako bi od tih tijela ishodio pokretanje nekog postupka, ispunjenje neke svoje molbe ili, primjerice, kako bi im uputio neku svoju primjedbu, komentar ili sugestiju - radi obuhvaćanja što većeg broja podnesaka pod primjenu čl. 46. Ustava. Nadalje, rokove za davanje odgovora na predstavku, kao i trenutak od kojega taj rok počinje teći, trebalo bi uskladiti u svim propisima (primjerice, određujući da rok za odgovor traje 30 dana, a počinje teći od dana zaprimanja predstavke), s time da bi pravo na predstavku pripadalo svakome, sukladno čl. 46. Ustava, uz propisivanje sankcija za 
onemogućavanje ostvarenja toga ustavnog prava po uzoru na čl. 46. st. 1. t. 10. Zakona o službenicima i namještenicima u lokalnoj i područnoj (regionalnoj) samoupravi.

Dakako, navedeni prijedlozi ujedno nameću pitanje načina na koji bi se moglo pristupiti promjenama važećega normativnog okvira. Iako bi usklađivanje normativnog okvira moglo biti provedeno izmjenama i/ili dopunama dosad izloženih zakona i drugih propisa, alternativu bi moglo predstavljati donošenje zakona kojim bi se sveobuhvatno uredilo postupanje po predstavkama, pritužbama i prijedlozima podnesenim državnim i drugim tijelima. Naime, po uvidu u usporedna pravna rješenja, može se primijetiti različit pristup uređenju predstavki na ustavnoj razini pravo na predstavku propisano je u nizu država, dok daljnja razrada toga ustavnog prava može biti izvedena parlamentarnim poslovnikom i/ili jednim posebnim ili više različitih zakona i podzakonskih propisa. Kada se samo jednim, posebnim zakonom uređuje postupanje po predstavkama i drugim podnescima, to je moguće učiniti takvim zakonskim rješenjem koje ne zahtijeva podrednu primjenu drugih zakona ili, pak, takvim zakonskim rješenjem koje predviđa da će se na pojedina pitanja koja nisu uređena tim zakonom na odgovarajući način primijeniti odredbe jednog ili više zakona. Stoga, može se uočiti da postoje primjeri država koje su posebnim zakonom uredile postupanje po podnescima, a takav poseban zakon ne bi predstavljao novum ni u hrvatskom pravnom poretku, budući da je u Republici Hrvatskoj do 1994. na snazi bio Zakon o radu organa koji postupaju po predstavkama i prijedlozima ${ }^{89}$ iz 1978. Tim zakonom bio je uređen rad tijela koja su postupala po predstavkama i prijedlozima koje su "radni ljudi i građani, organizacije udruženog rada te druge samoupravne organizacije i zajednice, društvene organizacije, udruženja građana ili druge građanske pravne osobe" podnosili tadašnjem Saboru Socijalističke Republike Hrvatske, Izvršnom vijeću Sabora, Predsjedništvu, kao i drugim tadašnjim republičkim tijelima, skupštinama općina i zajednica općina i tijelima tih društveno-političkih zajednica, a odredbe tog zakona primjenjivale su se i na postupak po predstavkama i prijedlozima koje su tim tijelima ustupila savezna tijela. Iako $\mathrm{u}$ tom zakonu od samo 15 članaka nije bilo definirano što se smatra predstavkom, ${ }^{90}$ niti je bio preciziran rok u kojemu su tijela bila obvezna dati na nju odgovor, ${ }^{91}$ niti su bile propisane sankcije za onemogućavanje ostvarenja tog prava, donošenjem takvog zakona moglo bi se otkloniti nedostatke važećega normativnog okvira i urediti postupanje po predstavkama (ali i pritužbama i prijedlozima) na jedinstven, pregledan i sveobuhvatan način.

Dakako, neovisno o pristupu za koji se zakonodavac u tom cilju odluči, morao bi se voditi za spomenutim načelima pravne sigurnosti, izvjesnosti i dosljednosti pri formuliranju zakonskih odredbi koje moraju biti jasne i precizne, napose imajući u vidu značaj prava iz čl. 46. Ustava i implikacije koje mogu imati njegove različite interpretacije. Tome bi trebala pripomoći

89 Narodne novine, broj 17/1978. Navedeni zakon prestao je važiti na temelju Zakona o prestanku važenja Zakona o radu organa koji postupaju po predstavkama i prijedlozima (Narodne novine, broj 72/1994) koji je stupio na snagu 18. listopada 1994. Razloge zakonodavca za propisivanjem prestanka važenja tog zakona vrlo vjerojatno bi valjalo potražiti u okolnosti da je već tada ustavno pravo na predstavke, pritužbe i prijedloge bilo uređeno nizom propisa, poput tadašnjeg Zakona o pučkom pravobranitelju (Narodne novine, broj 60/1992), Zakona o sustavu državne uprave (Narodne novine, broj 75/1993) i Zakona o lokalnoj samoupravi i upravi (Narodne novine, broj 90/1992, 94/1993, 117/1993).

90 U tom zakonu nije postojalo jasno razlikovanje pojma predstavke i pritužbe, već je pritužba bila obuhvaćena, zajedno s ostalim podnescima, skupnim izrazom "predstavke i prijedlozi". Naime, pod predstavkama i prijedlozima, prema tom zakonu, smatrale su se molbe, pritužbe i drugi podnesci koji su se podnosili radi ostvarivanja i zaštite prava, pravnih interesa ili radi pokretanja političke ili druge inicijative od općeg interesa (čl. 2.).

91 Prema čl. 5. st. 1. tog Zakona tijela su bila obvezna primiti predstavku ili prijedlog, "što prije" uzeti u razmatranje i postupiti u skladu s tim zakonom i drugim propisima te "odmah" obavijestiti u pisanom obliku podnositelja što je po njima poduzeto. 
izričita odredba čl. 174. st. 1 podst. 4. Poslovnika Hrvatskoga sabora prema kojoj bi jasnoća sadržaja i smisla pojedine zakonske odredbe trebala biti osigurana već iz sâmog prijedloga zakona koji, među ostalim, obvezno sadrži i "tekst prijedloga zakona, s obrazloženjem”, ali i Jedinstvena metodološko-nomotehnička pravila za izradu akata koje donosi Hrvatski sabor ${ }^{92}$ čijim se donošenjem nastojalo osigurati upravo jedinstvenu metodologiju, "pravno usuglašen i nomotehnički ujednačen izričaj u aktima Hrvatskoga sabora" ${ }^{33}$ kako bi se otklonilo eventualne nedosljednosti i dvojbenosti u tekstu zakona (i drugog akta), kao i u njegovoj primjeni.

\section{LITERATURA}

1. Bačić, A., Komentar Ustava Republike Hrvatske, Pravni fakultet Sveučilišta u Splitu, Split, 2002.

2. Hrvatski sabor, Poslovnik Sabora Kraljevinah Hrvatske, Slavonije i Dalmacije od 12. lipnja 1875., Tiskom Lav. Hartmána i družbe, Zagreb, 1875.

3. Ivančević, V., Institucije upravnog prava, knj. I., Pravni fakultet u Zagrebu, Zagreb, 1983.

4. Japunčić, J., Kako se sastavljaju molbe, žalbe i predstavke, Birotehnika, Zagreb, 1956.

5. Juras, D., Neka pitanja postupka po predstavkama i pritužbama s osvrtom na praksu Ministarstva unutarnjih poslova, Zbornik radova Pravnog fakulteta u Splitu, god. 36, br. 1-2, 1999., str. 329.-343.

6. Juras, D., O predstavkama i pritužbama Ministarstvu unutarnjih poslova Republike Hrvatske, Zbornik radova Pravnog fakulteta u Splitu, god. 50, br. 3, 2013., str. 643.-660.

7. Juras, D., Predstavke i pritužbe na rad i ponašanje državnih službenika, državnih odvjetnika i sudaca, Hrvatska pravna revija, god. 8, br. 12, 2008., str. 11-18.

8. Krbek, I., Osnovi upravnog prava FNRJ, Izdavački zavod JAZU, Zagreb, 1950.

9. Ożóg, M., Uregulowanie instytucji petycji w ustawie z dnia 11 lipca 2014 r. o petycjach, Przegląd Sejmowy, god. 23, br. 5, 2015., str. 117.-142.

10. Pezo, V. (gl. ur.), Pravni leksikon, Leksikografski zavod “Miroslav Krleža”, Zagreb, 2007.

11. Pusić, E.; Ivanišević, S.; Pavić, Ž.; Ramljak, M., Upravni sistemi, Narodne novine, Zagreb, 1988.

12. Ravlić, S., Dileme političkog predstavništva, Politička kultura, Zagreb, 2008.

13. Smolčić, P., Značaj predstavke u zaštiti ljudskih prava i suzbijanju korupcije, Policija i sigurnost, god. 18, br. 3, 2009., str. 348.-363.

14. Sokol, S.; Valković, Lj., Komentar Ustava Socijalističke Federativne Republike Jugoslavije, CIP, Zagreb, 1990.

15. Smerdel, B., Sokol, S., Ustavno pravo, Pravni fakultet Sveučilišta u Zagrebu, Zagreb, 2006.

16. Smerdel, B., Ustavno uređenje europske Hrvatske, Narodne novine, Zagreb, 2013.

17. Smolčić, P., Predstavke na rad zaposlenika i ustrojstvenih jedinica MUP-a RH, Policija i sigurnost, god. 16, br. 3-4, 2007., str. 201.-219.

18. Sruk, J., Ustavno uređenje Socijalističke Federativne Republike Jugoslavije, Informator, Zagreb, 1982.

19. Struić, G., Vjerodostojno tumačenje zakona u hrvatskom parlamentarnom pravu od 1947. do danas, Hrvatska i komparativna javna uprava, god. 16, br. 3, 2016., str. 553.-585.

92 Narodne novine, broj 74/2015.

93 Vidi pobliže: Struić, G., Vjerodostojno tumačenje zakona u hrvatskom parlamentarnom pravu od 1947. do danas, Hrvatska i komparativna javna uprava, god. 16, br. 3, 2016., str. 582. 
20. Šulek, B., Hrvatsko-ugarski ustav ili konstitucija, Brzotis Ant. Jakića, Zagreb, 1861.

21. Uzelac, A., Ustavno pravo na žalbu u građanskim stvarima: jamstvo ispravnog pravosuđenja ili relikt prošlosti?, u: A. Uzelac; J. Garašić; A. Maganić (ur.), Djelotvorna pravna zaštita u pravičnom postupku (Liber amicorum Mihajlo Dika), Pravni fakultet Sveučilišta u Zagrebu, Zagreb, 2013., str. 219.-243.

22. Vidaković-Mukić, M., Opći pravni rječnik, Narodne novine, Zagreb, 2015.

\section{POPIS PROPISA, AKATA I SUDSKIH ODLUKA}

1. Etički kodeks državnih službenika, Narodne novine, broj 40/2011, 13/2012.

2. Jedinstvena metodološko-nomotehnička pravila za izradu akata koje donosi Hrvatski sabor, Narodne novine, broj 74/2015.

3. Kazneni zakon (1997), Narodne novine, broj 110/1997, 27/1998, 50/2000, 129/2000, 84/2005, 51/2001, 111/2003, 190/2003, 105/2004, 71/2006, 110/2007, 152/2008, 57/2011, 77/2011, 125/2011, 143/2012.

4. Kazneni zakon (2011), Narodne novine, broj 125/2011, 144/2012, 56/2015, 61/2015, 101/2017.

5. Odluka i Rješenje Ustavnog suda Republike Hrvatske broj: U-I-3843/2007 od 6. travnja 2011., Narodne novine, broj 48/2011.

6. Odluka i Rješenje Ustavnog suda Republike Hrvatske broj: U-I-4039/2009, U-I-25427/2009 i U-I195/2010 od 18. srpnja 2014., Narodne novine, broj 100/2014.

7. Odluka i Rješenje Ustavnog suda Republike Hrvatske broj: U-I-659/1994, U-I-146/1996, U-I228/1996, U-I-508/1996, U-I-589/1999 od 15. ožujka 2000., Narodne novine, broj 31/2000.

8. Odluka i Rješenje Ustavnog suda Republike Hrvatske broj: U-I-722/2009 od 6. travnja 2011., Narodne novine, broj 44/2011.

9. Odluka Ustavnog suda Republike Hrvatske broj U-II-1744/2001 od 11. veljače 2004., Narodne novine, broj 21/2004.

10. Odluka Ustavnog suda Republike Hrvatske broj U-III-234/1998 od 28. travnja 1999., Narodne novine, broj 46/1999.

11. Poslovnik Hrvatskoga sabora, Narodne novine, broj 81/2013, 113/2016, 69/2017.

12. Poslovnik Sabora Narodne Republike Hrvatske, Narodne novine, broj 57/1958.

13. Poslovnik Sabora Socijalističke Republike Hrvatske, Narodne novine, broj 22/1965.

14. Poslovnik Ustavotvornog sabora Narodne Republike Hrvatske, Narodne novine, broj 143/1946.

15. Povelja Europske unije o temeljnim pravima, Službeni list EU, C 202/02 od 7. lipnja 2016.

16. Pravilnik o načinima, postupcima i elementima vrednovanja učenika u osnovnoj i srednjoj školi, Narodne novine, broj 112/2010.

17. Pravilnik o načinu rada i postupanja po predstavkama i pritužbama, vođenju Evidencije predstavki i pritužbi te o radu Povjerenstva, Narodne novine, broj 58/2012, 43/2013, 33/2015, 78/2015.

18. Pravilnik o načinu rada i postupanja po pritužbama te radu povjerenstava za rad po pritužbama, Narodne novine, broj 78/2015.

19. Pravilnik o nadzoru nad provedbom Zakona o javnoj nabavi, Narodne novine, broj 65/2017.

20. Pravilnik o postupku s predstavkama i pritužbama, Narodne novine, broj 142/1999.

21. Pravilnik o provođenju unutarnjeg nadzora i unutarnje kontrole u Carinskoj upravi, Narodne novine, broj 153/2013. 
22. Rješenje Ustavnog suda Republike Hrvatske broj: U-I-3101/2014 i dr. od 12. siječnja 2015., Narodne novine, broj 5/2015.

23. Ugovor o funkcioniranju Europske unije, Službeni list EU, C 202/01 od 7. lipnja 2016.

24. Ustav Narodne Republike Hrvatske, Narodne novine, broj 7/1947.

25. Ustav Republike Hrvatske, Narodne novine, broj 56/1990, 135/1997, 8/1998, 113/2000, 124/2000, 28/2001, 41/2001, 55/2001, 76/2010, 85/2010, 5/2014.

26. Zakon o državnim službenicima, Narodne novine, broj 92/2005, 140/2005, 142/2006, 77/2007, 107/2007, 27/2008, 34/2011, 49/2011, 150/2011, 34/2012, 38/2013, 37/2013, 1/2015, 138/2015, $61 / 2017$

27. Zakon o državnom odvjetništvu, Narodne novine, broj 76/2009, 153/2009, 116/2010, 145/2010, 57/2011, 130/2011, 72/2013, 148/2013, 33/2015, 82/2015.

28. Zakon o inspekcijama u gospodarstvu, Narodne novine, broj 14/2014, 56/2016.

29. Zakon o lokalnim izborima, Narodne novine, broj 144/2012, 121/2016.

30. Zakon o lokalnoj samoupravi i upravi, Narodne novine, broj 90/1992, 94/1993, 117/1993.

31. Zakon o lokalnoj i područnoj (regionalnoj) samoupravi, Narodne novine, broj 33/2001, 60/2001, 129/2005, 109/2007, 36/2009, 125/2008, 36/2009, 150/2011, 144/2012, 19/2013, 137/2015, $123 / 2017$.

32. Zakon o općem upravnom postupku, Narodne novine, broj 47/2009.

33. Zakon o osiguranju, Narodne novine, broj 30/2015.

34. Zakon o policiji, Narodne novine, broj 34/2011, 130/2012, 89/2014, 151/2014, 33/2015, 121/2016.

35. Zakon o pravu na pristup informacijama, Narodne novine, broj 25/2013, 85/2015.

36. Zakon o prestanku važenja Zakona o radu organa koji postupaju po predstavkama i prijedlozima, Narodne novine, broj 72/1994.

37. Zakon o proračunu, Narodne novine, broj 87/2008, 109/2007, 136/2012, 15/2015.

38. Zakon o pučkom pravobranitelju (1992), Narodne novine, broj 60/1992.

39. Zakon o pučkom pravobranitelju (2012), Narodne novine, broj 76/2012.

40. Zakon o radu organa koji postupaju po predstavkama i prijedlozima, Narodne novine, broj 17/1978.

41. Zakon o referendumu i drugim oblicima osobnog sudjelovanja u obavljanju državne vlasti i lokalne i područne (regionalne) samouprave, Narodne novine, broj 33/1996, 92/2001, 44/2006, 58/2006, 69/2007, 38/2009, 100/2016, 73/2017.

42. Zakon o službenicima i namještenicima u lokalnoj i područnoj (regionalnoj) samoupravi, Narodne novine, broj 86/2008, 61/2011, 4/2018.

43. Zakon o sudovima, Narodne novine, broj 28/2013, 33/2015, 82/2015, 82/2016.

44. Zakon o sustavu državne uprave (1993), Narodne novine, broj 75/1993.

45. Zakon o sustavu državne uprave (2011), Narodne novine, broj 150/2011, 12/2013, 93/2016, 104/2016.

\section{MREŽNI IZVORI}

1. e-Doc baza podataka Hrvatskoga sabora, URL=http://edoc.sabor.hr. Pristupljeno 28. veljače 2018.

2. Hrvatski jezični portal, URL=http://hjp.znanje.hr. Pristupljeno 28. veljače 2018. 
3. Interna pravila o radu Odbora (Вътрешни правила за работата на Комисията), URL=http://www. parliament.bg/bg/parliamentarycommittees/members/2592/info. Pristupljeno 28. veljače 2018.

4. Izvješće ministra unutarnjih poslova o obavljanju policijskih poslova u 2016. godini, URL=http:// www.sabor.hr/fgs.axd?id=49056. Pristupljeno 28. veljače 2018.

5. Izvješće o aktivnostima Odbora za predstavke Europskog parlamenta tijekom 2015. od 2. prosinca 2016. (2016/2146(INI)), URL=http://www.europarl.europa.eu/sides/get Doc.do?pubRef=//EP// TEXT+REPORT+A8-2016-0366+0+DOC+XML+V0//HR. Pristupljeno 28. veljače 2018.

6. Izvješće o provedbi Zakona o pravu na pristup informacijama za 2016. godinu, URL=http://www. sabor.hr/fgs.axd?id=48819. Pristupljeno 28. veljače 2018.

7. Izvješće o radu Agencije za zaštitu osobnih podataka za 2016. godinu, URL=http://www.sabor.hr/ fgs.axd?id=49669. Pristupljeno 28. veljače 2018.

8. Izvješće o radu Državnog odvjetništva Republike Hrvatske za 2016. godinu, URL=http://www.sabor.hr/fgs.axd?id=48956. Pristupljeno 28. veljače 2018.

9. Izvješće o radu Hrvatske energetske regulatorne agencije za 2016. godinu, URL=http://www.sabor. hr/fgs.axd?id=49766. Pristupljeno 28. veljače 2018.

10. Izvješće o radu Odbora za predstavke i pritužbe za 2016. godinu, URL=http://www.sabor.hr/fgs. axd?id=48551. Pristupljeno 28. veljače 2018.

11. Izvješće pučke pravobraniteljice za 2016. godinu, URL=http://www.sabor.hr/fgs.axd?id=48673. Pristupljeno 28. veljače 2018.

12. Mađarski Temeljni zakon (Magyarország Alaptörvénye), URL=www.parlament.hu/irom39/02627/02627.pdf. Pristupljeno 28. veljače 2018.

13. Načela Odbora za peticije o postupanju sa zamolbama i pritužbama (Grundsätze des Petitionsausschusses über die Behandlung von Bitten und Beschwerden), URL=https:// www.bundestag.de/ ausschuesse/ausschuesse18/a02-18/grundsaetze/verfahrensgrund saetze/260564. Pristupljeno 28. veljače 2018.

14. Narodna skupština Republike Srbije, URL=http://www.parlament.gov.rs/gradjani/pitajte/ inicijative,-peticije,-predstavke-i-predlozi.1098.html. Pristupljeno 28. veljače 2018.

15. Poslovnik Europskog parlamenta, s Prilogom VI., URL=http://www.europarl.europa.eu/ sipade/ rules/20170116/Rules20170116-HR.epub. Pristupljeno 28. veljače 2018.

16. Poslovnik Narodne skupštine (Пословник Народне скупштине), URL=http://www. parlament.gov. rs/upload/documents/Poslovnik\%20Narodne\%20skupstine\%20-\%20 precisceni\%20tekst\%20Sluzbeni\%20g.pdf. Pristupljeno 28. veljače 2018.

17. Poslovnik njemačkog Bundestaga (Geschäftsordnung des Deutschen Bundestages), URL=http:// www.bundestag.de/parlament/aufgaben/rechtsgrundlagen/go-btg/go-btg/ 197104. Pristupljeno 28. veljače 2018.

18. Poslovnik Sejma Republike Poljske (Regulamin Sejmu Rzeczypospolitej Polskiej), URL=http://www. sejm.gov.pl/prawo/regulamin/kon7.htm. Pristupljeno 28. veljače 2018.

19. Poslovnik Senata Republike Poljske od 23. studenoga 1990. (Uchwała Senatu Rzeczypospolitej Polskiej z dnia 23 listopada 1990.; URL=https://www.senat.gov.pl/download/gfx/senat/pl/defaultopisy/86/1/1/regulamin-z-12-lutego-2018.pdf. Pristupljeno 28. veljače 2018.

20. Poslovnik Skupštine Republike (Regimento da Assembleia da República), URL=http://www.parlamento.pt/Legislacao/Documents/Legislacao-Anotada/Regimento AR-Simples.pdf. Pristupljeno 28. veljače 2018.

21. Pravilnik o ustrojstvu i radu Narodne skupštine (Правилник за организацията и дейността на Народното Събрание), URL=http://www.parliament.bg/bg/rulesofthe organisations. Pristupljeno 28. veljače 2018. 
22. Presuda Europskog suda za ljudska prava u predmetu Beian protiv Rumunjske, od 6. prosinca 2007., zahtjev br. 30658/05, URL=http://www.legal-tools.org/doc/a40617/pdf/. Pristupljeno 28. veljače 2018.

23. Protokol o postupanju po predstavkama i pritužbama, URL=http://www.mspm.hr/ istaknute -teme/nadzor-i-predstavke/protokol-o-postupanju-po-predstavkama-i-prituzb ama/880. Pristupljeno 28. veljače 2018.

24. Rajko, A., Predstavke (požurnice) upućene predsjednicima sudova, 2016. URL=http://www.iusinfo. com.hr/DailyContent/Topical.aspx?id=28440. Pristupljeno 28. veljače 2018.

25. Savezni zakon o postupku razmatranja obraćanja građana Ruske Federacije (Федеральный закон о порядке рассмотрения обращений граждан Российской Федерации), URL=http://pravo.gov.ru/ proxy/ips/?docbody=\&nd=102106413. Pristupljeno 28. veljače 2018.

26. Temeljni zakon Savezne Republike Njemačke (Grundgesetz für die Bundesrepublik Deutschland), URL=http://www.gesetze-im-internet.de/gg/index.html. Pristupljeno 28. veljače 2018.

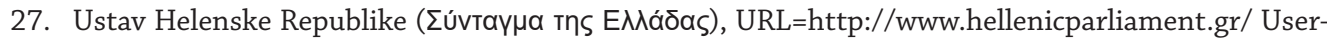
Files/f3c70a23-7696-49db-9148-f24dce6a27c8/SYNTAGMA1-1.pdf. Pristupljeno 28. veljače 2018.

28. Ustav Portugalske Republike (Constituição da República Portuguesa), URL=http://www.parlamento.pt/Legislacao/Documents/constpt2005.pdf. Pristupljeno 28. veljače 2018.

29. Ustav Republike Bugarske (Конституция на Република България), URL=http://www.parlia ment. bg/bg/const. Pristupljeno 28. veljače 2018.

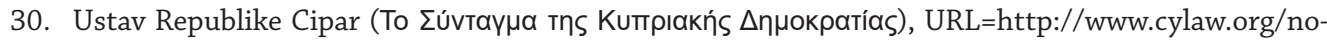
moi/enop/non-ind/syntagma/index.html. Pristupljeno 28. veljače 2018.

31. Ustav Republike Estonije (Eesti Vabariigi põhiseadus), URL=https://www.riigiteataja.ee/ akt/633949. Pristupljeno 28. veljače 2018.

32. Ustav Republike Makedonije (Устав на Република Македонија), URL=https://www.sobranie.mk/ WBStorage/Files/UstavnaRmizmeni.pdf. Pristupljeno 28. veljače 2018.

33. Ustav Republike Poljske (Konstytucja Rzeczypospolitej Polskiej), URL=http://www.sejm.gov.pl/ prawo/konst/polski/kon1.htm. Pristupljeno 28. veljače 2018.

34. Ustav Republike Slovenije (Ustava Republike Slovenije), URL=http://www.pisrs.si/Pis.web/pregledPredpisa?id=USTA1. Pristupljeno 28. veljače 2018.

35. Ustav Republike Srbije (Устав Републике Србије), URL=http://www.parlament.gov.rs/upload/documents/Ustav-Srbije-pdf.pdf. Pristupljeno 28. veljače 2018.

36. Ustav Ruske Federacije (Конституция Российской Федерации), URL=http://www.ksrf.ru/ru/Info/ LegalBases/ConstitutionRF/Pages/default.aspx. Pristupljeno 28. veljače 2018.

37. Ustav Slovačke Republike (Ústava Slovenskej republiky), URL=http://www.nrsr.sk/web/Static/skSK/NRSR/Doc/zd-ustava-20170907.pdf. Pristupljeno 28. veljače 2018.

38. Zakon broj 43/90, od 10. kolovoza (Lei n. ${ }^{\circ} 43 / 90$, de 10 de agosto), URL=http://www.parlamento. pt/legislacao/documents/legislacao-anotada/exerciciodireitopeticao-anotado.pdf. Pristupljeno 28. veljače 2018.

39. Zakon o državnim tajnama i klasificiranim informacijama o stranim državama (Riigisaladuse ja salastatud välisteabe seadus), URL=https://www.riigiteataja.ee/akt/105052017005. Pristupljeno 28. veljače 2018.

40. Zakon o internim i postupovnim pravilima Riigikogua (Riigikogu kodu - ja töökorra seadus), URL=https://www.riigiteataja.ee/akt/128062016022. Pristupljeno 28. veljače 2018.

41. Zakonokancelarupravde(Õiguskantsleriseadus), URL=https://www.riigiteataja.ee/akt/128122017020. Pristupljeno 28. veljače 2018. 
42. Zakon o Narodnoj skupštini (Закон о Народној скупштини), URL=http://www.parlament.gov.rs/ upload/documents/412-10.pdf. Pristupljeno 28. veljače 2018.

43. Zakon o ovlastima Odbora za peticije njemačkog Bundestaga (Gesetz über die Befugnisse des Petitionsausschusses des Deutschen Bundestages), URL=https://www.gesetze-im-internet.de/ ggart45cg/GGArt45cG.pdf. Pristupljeno 28. veljače 2018.

44. Zakon o upravnom postupku od 14. lipnja 1960. (Ustawa z dnia 14 czerwca $1960 \mathrm{r}$. Kodeks postępowania administracyjnego), URL=http://prawo.sejm.gov.pl/isap.nsf/download.xsp/WDU 19600300168/O/ D19600168.pdf. Pristupljeno 28. veljače 2018.

45. Zakon o zaštiti potrošača (Tarbijakaitseseadus), URL=https://www.riigiteataja.ee/akt/128122017033. Pristupljeno 28. veljače 2018.

46. Zakon od 11. srpnja 2014. o peticijama (Ustawa z dnia 11 lipca 2014 r. o petycjach), URL=http:// prawo.sejm.gov.pl/isap.nsf/download.xsp/WDU20140001195/T/D20141195L.pdf. Pristupljeno 28. veljače 2018. 


\section{LEGAL REGULATION OF THE PETITIONS IN THE REPUBLIC OF CROATIA - THE QUESTION OF ITS NORMATIVE FRAMEWORK COHERENCE, POTENTIAL APPLICATION PROBLEMS AND SOLUTIONS}

\section{Summary}

Starting from the fact that the constitutional right to petition is governed by a series of different laws and regulations in the Republic of Croatia, the paper aims at answering the question of coherence of its normative framework. To this end, the author outlines the conceptual definition of the petition, presents its legal regulation in the Republic of Croatia, examines the differences in the current normative framework, as well as possible problems arising from the arrangement of this constitutional right, suggesting potential solutions. In addition, the author considers the actual effects of regulations, as well as various approaches in comparative law. On this basis, the conclusion has been drawn that the normative framework for the regulation of petitions is incoherent due to differences in terminology, the absence of constitutional and legal definition of the petition, different deadlines for the response to the petition, differences in the context of authorized petitioners, and differences regarding sanctions for the persons who hinder exercising of this constitutional right.

Keywords: $\quad$ petition, complaint, motion, Constitution

\section{(c) (1) (8)}

This work is licensed under a Creative Commons

Attribution-NonCommercial 4.0 International License.

* Gordan Struić, master of laws and university specialist in comparative politics, Croatian Parliament, Trg svetoga Marka 6, 10000 Zagreb, Republic of Croatia. Email address: gordan.struic@gmail.com. ORCID: http://orcid.org/0000-0001-6528-4436.

The views expressed here are solely those of the author. 